NBER WORKING PAPER SERIES

\title{
THE GEOGRAPHY OF PRESCRIPTION PHARMACEUTICALS SUPPLIED TO THE U.S.: LEVELS, TRENDS AND IMPLICATIONS
}

\author{
Neriman Beste Kaygisiz \\ Yashna Shivdasani \\ Rena M. Conti \\ Ernst R. Berndt \\ Working Paper 26524 \\ http://www.nber.org/papers/w26524 \\ NATIONAL BUREAU OF ECONOMIC RESEARCH \\ 1050 Massachusetts Avenue \\ Cambridge, MA 02138 \\ December 2019
}

Ms. Conti acknowledges research support from the Commonwealth Fund and the American Cancer Society. Mr. Berndt acknowledges research support from the National Institutes of Health, National Institute on Aging, Grant R01AG043560 to the National Bureau of Economic Research. We have benefited from discussions on FDA regulatory and user fee payment file matters with Dr. Andreas Schick and Qiyu Liu of the U.S. Food and Drug Administration, from access to manufacturing facility geographic data provided by the U.S. Food and Drug Administration, and from data sources identified by Dr. Chris Stomberg of National Economic Research Associates. Any opinions and findings expressed here are those of the authors, are not necessarily those of the institutions with whom they are affiliated, the research sponsors, nor of the individuals and institutions providing us information, nor of the National Bureau of Economic Research.

NBER working papers are circulated for discussion and comment purposes. They have not been peer-reviewed or been subject to the review by the NBER Board of Directors that accompanies official NBER publications.

(C) 2019 by Neriman Beste Kaygisiz, Yashna Shivdasani, Rena M. Conti, and Ernst R. Berndt. All rights reserved. Short sections of text, not to exceed two paragraphs, may be quoted without explicit permission provided that full credit, including $\odot$ notice, is given to the source. 
The Geography of Prescription Pharmaceuticals Supplied to the U.S.: Levels, Trends and Implications

Neriman Beste Kaygisiz, Yashna Shivdasani, Rena M. Conti, and Ernst R. Berndt

NBER Working Paper No. 26524

December 2019

JEL No. F61,I18,K23,L51,L65

\section{$\underline{\text { ABSTRACT }}$}

Prescription pharmaceuticals are frequently used consumer products, whose manufacturing location is commonly held as a trade secret by firms and U.S. regulatory agencies. Here we use previously non-publicly available data to describe levels and trends in the manufacturing locations of the most commonly used prescription pharmaceuticals, off-patent generic drugs, intended to be consumed by Americans. We find that the base ingredients required for the manufacturing of these prescription drugs are overwhelmingly and increasingly manufactured in non-domestic locations, specifically India and China. The manufacturing of finished prescription drugs for the American market is equally split between domestic and foreign locations, but is increasingly foreign as well. The growing American reliance on non-domestic manufacturing of prescription drugs is important for stakeholders to appreciate given current quality and pricing concerns involving these products and their potential susceptibility to interruptions in supply. We discuss implications of these levels and trends for current domestic and international policy discussions.

Neriman Beste Kaygisiz

Wellesley College

Unit:4725

21 Wellesley College Road

Wellesley, Mass 02481

nkaygisi@wellesley.edu

Yashna Shivdasani

Wellesley College

Unit 6121,

106 Central Street

Wellesley, MA 02481

yshivdas@wellesley.edu
Rena M. Conti

Boston University

Questrom School of Business

Department of Markets, Public Policy and Law

595 Commonwealth Ave

Boston, MA 02215

rconti@bu.edu

Ernst R. Berndt

MIT Sloan School of Management

100 Main Street, E62-533

Cambridge, MA 02142

and NBER

eberndt@mit.edu 


\section{INTRODUCTION}

This paper documents the geography of manufacturing among a very commonly used product by American consumers, 'off-patent' generic prescription drugs. Our empirical focus on this product is highly relevant and salient for a number of reasons. The U.S. is the world's largest pharmaceutical drug market; Nearly 70 percent of Americans are on at least one prescription drug, and more than half take two. ${ }^{1}$ U.S. demand for generic drugs has grown substantially in the last few decades, reflecting in part the accumulated track record of safety, efficacy and relatively low prices. More than $90 \%$ of pharmaceutical drug prescriptions in the U.S. are currently dispensed as generic drugs. ${ }^{2}$

In recent years, the geographic sources of prescription drugs consumed by Americans have also become prominent in the popular press and public policy discussions. ${ }^{3,4}$ While the U.S. is a world leader in developing and marketing 'on-patent' branded prescription drugs, numerous reports have suggested increasingly the manufacturing of generic drugs intended for

\footnotetext{
${ }^{1}$ https://www.consumerreports.org/prescription-drugs/too-many-meds-americas-love-affair-with-prescriptionmedication/

${ }^{2}$ IQVIA Institute for Human Data Science, Medicine Use and Spending in the U.S.: A Review of 2017 and Outlook to 2022, Parsippany, NJ, April 2018, p, 14. Available online at https://www.iqvia.com/institute/reports....

${ }^{3}$ https://www.cbsnews.com/news/worse-than-you-think-10-things-you-dont-know-about-glaxos-750m-paxilsettlement/

${ }^{4}$ For one account focusing on drug quality and safety controversies, see Katherine Eban, Bottle of Lies: The Inside Story of the Generic Drug Boom, New York: HarperCollins Publishers, 2019. Concerns over the US Food and Drug Administration's track record in inspecting foreign manufacturing sites led the US Congress in 2012 in part to pass the Generic Drug User Fee Act legislation. For discussion, see Ernst R. Berndt, Rena M. Conti and Stephen J. Murphy, "The generic drug user fee amendments: an economic perspective", Journal of Law and the Biosciences, lsy002, https:doi.org/10.1093/jlb/lsy002, published 11 April 2018. For a discussion of drug shortage issues, see Christopher Stomberg, "Drug Shortages, Pricing and Regulatory Activity”, ch. 10 in Ana Aizcorbe, Colin Baker, Ernst R. Berndt and David M. Cutler, eds., Measuring and Modeling Health Care Costs, Chicago: University of Chicago Press for the National Bureau of Economic Research, 2018, pp. 323-348; and Rena M. Conti and Ernst R. Berndt, "Specialty Drug Prices and Utilization After Loss of US Patent Exclusivity, 2001-2007”, ch. 9 in Aizcorbe, Baker, Berndt and Cutler [2018], op. cit., pp. 273-321.
} 
U.S. consumption is occurring abroad, particularly in China and India. ${ }^{5,6}$ Vulnerabilities in the supply of drugs, including generics, has been linked to drug quality and safety concerns, and notably geography-based concerns including weather-related events impacting domestic production and controversies involving international trade provisions among foreign manufacturers. ${ }^{7}$ Very high prices and price spikes have also been noted among specific generic prescription drugs in the U.S., which may be related to supply or quality concerns. ${ }^{8}$ Quality concerns and potential supply interruptions are surprising in part because in order to be sold in the U.S. market, prescription drugs must meet or exceed very stringent regulatory standards for safety, purity and efficacy set by the U.S. authority in charge of regulating these products, the U.S. Food and Drug Administration (“FDA”). ${ }^{9}$

This paper builds on previous research that distinguished U.S. from non-U.S. manufacturing sources of generic prescription drugs between 2013 and 2017, based on previously non-public data provided us by the FDA. ${ }^{10}$ Here, we report updated findings through

\footnotetext{
${ }^{5}$ Rena M. Conti and Ernst R. Berndt, "Four Facts Concerning Competition in U.S. Generic Prescription Drug Markets”, International Journal of the Economics of Business, August 2019. DOI:

10.1080/13571516.2019.1654324; Ernst R. Berndt and Murray L. Aitken, "Brand Loyalty, Generic Entry and Price Competition in Pharmaceuticals in the Quarter Century after the 1984 Waxman-Hatch Legislation”, International Journal of the Economics of Business, 2011, 18(2): 177-201.

${ }^{6}$ Ernst R. Berndt, Rena M. Conti and Stephen J. Murphy [2018], op. cit. Jasdeep Singh, Mohit Jain and Pratyush Goel, US Generics Market-Evolution of Indian Players, IQVIA Institute for Human Data Science, February 2019. Available online from www.IQVIA.com; Kyle Blankenship, “As API production consolidates abroad, U.S. regulators face safety concerns at home”, Fierce Pharma, August 29, 2019. Available online at https://www.fiercepharma.com/pharma/half-fda-warnings-letters-last-year-were-seng-to-in...

${ }^{7}$ For one account focusing on drug quality and safety controversies, see Katherine Eban [2019], op. cit. Concerns over the US Food and Drug Administration's track record in inspecting foreign manufacturing sites led the US Congress in 2012 in part to pass the Generic Drug User Fee Act legislation. For discussion, see Ernst R. Berndt, Rena M. Conti and Stephen J. Murphy [2018], op. cit. For a discussion of drug shortage issues, see Christopher Stomberg [2018], op. cit.; and Rena M. Conti and Ernst R. Berndt, [2018], op. cit.,

${ }^{8}$ Conti RM, Nguyen KH, Rosenthal MB. “Generic prescription drug price increases: which products will be affected by proposed anti-gouging legislation?” J Pharm Policy Pract. 2018 Nov 21;11:29.

9 https://www.fda.gov/drugs/drug-information-consumers/protecting-americas-health-through-human-drugs

${ }^{10}$ Berndt, Conti and Murphy [2018], op. cit.
} 
2019 and more regionally disaggregated geographies (various non-U.S. countries and global regions, and 19 regions within the U.S.) based on new data provided to us by the FDA.

To place these manufacturing geography levels and trends into context, we first briefly describe the existing international trade theoretical literature that underpins rationales for why regions and countries specialize in the manufacturing of certain products for domestic consumption, and then specialize further by expanding into export markets. This involves a review of the relevant economic literature on comparative advantage, and on economies of scale and scope - longstanding economic rationales motivating firms' choice of manufacturing geography. Moreover, the economic literature explains that firms' manufacturing geography opportunities arise in large part endogenously and reflect historical choices made by firms and public policy makers, including the use of tools such as rules promoting public safety, tax provisions, tariffs, trade policy and even human capital investments. Given this, we provide a brief summary of the relevant regulatory provisions for the manufacture and sale of prescription drugs in the U.S. and an historical account of private and public sector policies adopted in four geographies - Puerto Rico, India, China, and Ireland - that are particularly important to the U.S. generic drug market; an Appendix provides a more detailed historical narrative and references. With this as background, we present our updated and geographically disaggregated global and U.S. domestic findings. In the final section, we discuss implications of the geography of generic drug manufacturing for current domestic and international policy developments.

\section{PLANT LOCATION, SCALE ECONOMIES AND THE BASICS OF ECONOMIC GEOGRAPHY}

What economists observe in numerous industries is that regions and countries (hereafter, regions) specialize in what they produce for domestic consumption and export, creating patterns 
of economic geography. ${ }^{11}$ These factors should be viewed as acting in a complementary fashion with regulatory, tax and industrial policy.

\section{II.A Specialization, Trade and Comparative Advantage: It Pays to be Different}

Holding all else equal, it is widely thought there are two primary reasons for why some regions specialize in manufacturing and exporting certain products. First, regions differ in the relative abundance of resources (water, forests, climate, minerals, supply of skilled and unskilled labor) and/or in their production technology (the intensity with which they utilize various factors of production in the production of different goods), and then specialize in the things they do relatively well. According to the classic Heckscher-Ohlin theory of comparative advantage, trade between regions is based in large part on differences among regions, with regions tending to produce relatively more of and export goods that are intensive in the factors with which they are abundantly endowed. ${ }^{12}$ However, in terms of predicting a country's content of international trade, empirical evidence is mixed on the Hecksher-Ohlin model. As a leading textbook states, while "the Heckscher-Ohlin model does a good job of predicting the pattern of trade between developed and developing countries", 13 its heavy reliance on differences between regions as the primary reason underpinning interregional trade limits its usefulness in understanding current trade patterns among regions.

\footnotetext{
${ }^{11}$ Although there are numerous textbooks on international economics and trade, here we rely primarily on one widely used international trade textbook, Paul R. Krugman, Maurice Obstfeld and Marc J. Melitz, International Trade: Theory and Policy, Eleventh Edition, New York: Pearson Education, Inc., 2018, especially chapters 3-8 and 11.

12 For an extended discussion of the Heckscher-Ohlin framework, see Krugman, Obstfeld and Melitz [2018], op. cit., especially chapter 5, "Resources and Trade: The Heckscher-Ohlin Model”, pp. 87-122.

${ }^{13}$ Krugman, Obstfeld and Melitz [2018], op. cit., p. 115.
} 
A second reason why countries specialize in production and trade owes to economies of scale (also called increasing returns) that make it advantageous for a region to specialize in the production of only a limited range of goods and services. ${ }^{14}$ Economies of scale are said to occur when the industry's cost per unit falls as industry output increases; with fixed input prices, if quantities of all inputs double and output quantity more than doubles, cost per unit of industry output will decline manifesting economies of scale. Economists have theorized and observed that the particular type of scale economies impacts the size distribution of firms: Whether the industry size distribution of firms in a region is dominated by a small number of large firms or a large number of small firms depends in part on whether scale economies are primarily internal or external. In turn, the type of scale economies has important implications for industrial strategy and public policy on how best to locate and concentrate or agglomerate manufacturing plants.

\section{II.B Specialization, Trade, and External Scale Economies}

External economies of scale occur when the cost per unit depends on the overall size of the industry but not necessarily on the size of any one firm. An industry where economies of scale are purely external will typically consist of many small firms and often be very competitive; there will be no intrinsic advantages to larger firms. The analysis of external economies was originated by the British economist Alfred Marshall who was struck by the

\footnotetext{
14 This discussion that follows is based in large part on chapters 7, "External Economies of Scale and the International Location of Production", and chapter 8, "Firms in the Global Economy: Export Decisions, Outsourcing”, in Krugman, Obstfeld and Melitz [2018], op. cit., pp. 151-169 and 170-213, respectively.
} 
phenomenon of “industrial districts” or what today we might call "clusters” - geographical industry concentrations that could not easily be explained by natural resources. ${ }^{15}$

Marshall argued there are three main reasons why a geographic concentration of firms may be more efficient than an individual isolated firm: (i) the ability of a cluster of firms to support specialized suppliers. When there are a large number of firms, the regional agglomeration of specialized firms may provide a sufficiently viable and sustainable market for critical specialized equipment suppliers; (ii) a geographically concentrated industry allows labor pooling for workers with highly specialized skills. A pooled labor market provides advantages both to producers (who can locate, hire and train specialized workers) and to workers (who do not have to worry about becoming unemployed). Both workers and employers are better off if all are near each other; and (iii) a geographically concentrated industry helps foster informal knowledge spillovers that often are most prevalent when an industry is concentrated in a fairly small area, so that employees of different companies mix socially and talk freely about technical issues. Note that with each of these three sources of external scale economies, as industry size increases, the costs of available inputs decline, providing firm clusters with competitive cost advantages.

But this raises a more fundamental issue: from where did these external economies originally emanate? The answer is usually historical accident. Something gives a specific location an advantage in a particular industry, and this advantage gets "locked in" by external

\footnotetext{
15 Alfred Marshall, Principles of Economics, 1890. Reprinted London: Macmillan 1920 (8 ${ }^{\text {th }}$ edition). For a more contemporary discussion, see Michael E. Porter, The Competitive Advantage ofNations, New York: The Free Press, 1990, pp. 154-157.
} 
economies of scale even after the circumstances that created the initial advantage are no longer relevant. ${ }^{16}$

\section{II.C Specialization, Trade and Internal Scale Economies}

Internal scale economies can be analyzed in terms of three often overlapping categories: ${ }^{17}$ (i) product-specific internal scale economies associated with the volume of any single product made and sold; (ii) plant-specific scale and scope economies associated with the total outputs (possibly encompassing many products) of an entire plant or plant complex; and (iii) multi-plant economies associated with a firm's operation of multiple facilities in the same or different geographies.

Product-specific economies of scale derive in large part from specialization and the division of labor. A particularly important source of internal scale economies in the manufacturing of pharmaceuticals is the prominent role of vats, barrels and stainless steel reactors - containers holding solids and liquids used in the manufacturing processes of chemically synthesized small molecules, and in the fermentation of vaccines and biologics. Internal economies of scale at the product- and plant-specific level can be attained by expanding

\footnotetext{
${ }^{16}$ Consider, for example, the Chinese town of Qiaotou, that produces 60\% of the world's buttons and a large proportion of its zippers. The industry's origins lie in historical accident, but have been amplified by external scale economies. "In 1980, three brothers spotted some discarded buttons in the street, retrieved and sold them, and then realized there was money to be made in the button business...The town's button and zipper production is carried out by hundreds of small, family-owned firms. Yet there are clearly advantages to each of these small producers in operating in close proximity to the others.” Krugman, Obstfeld and Melitz [2018], op. cit., p. 161. While China's role in the 1980s and 1990s as a huge exporter of labor-intensive products surely reflected in part the forces of comparative advantage, many of these labor-intensive goods were produced by highly localized industries that benefited strongly from external economies of scale.

17 The discussion that follows is based in large part on F. M. Scherer and David Ross, Industrial Market Structure and Economic Performance, third edition [1990], chapter 4, "The Determinants of Market Structure: Economies of Scale”, pp. 97-151.
} 
the physical size of individual processing units. ${ }^{18}$ Moreover, since the crew needed to operate a large processing unit or machine is often little or no larger than what is required for a unit of smaller capacity, labor costs per unit fall sharply with scale-up. These relationships can operate at the product, plant and multi-plant level and thereby underpins internal economies of scale at various levels of aggregation.

An additional advantage of multi-plant size comes from what is commonly called "the economies of massed reserves”. A plant large enough to use only one specialized machine may need to hold another machine in reserve if it seeks to hedge against occasional breakdowns in order to sustain production. ${ }^{19}$ Moreover, the number of repair and maintenance staff a company must employ to maintain a desired level of service in the event of a random breakdown rises less than proportionately with the number of machines in operation, other things equal. Notably, these massed reserve economies can also be realized when unit shutdowns are predictable, or routinely required by insurers or regulators such as the FDA to meet current Good Manufacturing Practice (cGMP) standards (see below for more details). More generally, since every plant must carry some overhead, within limits cost savings can be realized by specializing overhead functions and spreading overhead over a larger volume. As Scherer and Ross note, “A large plant can have one or more specialized cost accountants, production schedulers, stock

\footnotetext{
${ }^{18}$ From basic geometry it is known that the area of a sphere or cylinder (e.g., boilers or reactors) varies as the twothirds power of volume, implying that the surface area increases less rapidly than the potential volume, generating product- and possibly plant-specific internal economies of scale. In the engineering literature this is known as the "two-thirds" or "six-tenths" rule, and it implies a rule of thumb that construction costs should increase by only 60$67 \%$ as output or capacity output doubles. For empirical support, see, for example, John Haldi and David Whitcomb, “Economies of Scale in Industrial Plants”, Journal of Political Economy, August 1967, 75(5):373-385. This intuition is often applied by engineers in estimating the cost of constructing new process equipment, such as that for bulk powders and active pharmaceutical ingredient processes.

${ }^{19}$ For a large plant with numerous machines, a single extra machine may provide almost the same degree of protection at much lower cost relative to total capacity carrying costs, provided the machine is fungible across products.
} 
keepers, nurses, plant guards, and so on. A small plant must often double up such functions, with possible skill losses”. ${ }^{20}$

Product- and plant-specific internal economies of scale may also interact in synergistic ways, particularly for multiproduct plants. When there are shared manufacturing inputs, such as boilers, pipes, and stainless steel reactors, manufacturing multiple products at a given plant can yield cost savings relative to manufacturing the various products in stand-alone plants; these cost savings are called economies of scope, and derive both from specialized equipment (e.g., machines making and filling syringes for various injectable drugs, making various oral solid drugs with tablet presses, providing sterile and aseptic storage areas for temporary inventory of goods in process) or from specialized labor (equipment operators, sterile manufacturing supervisors). Scope economies also occur frequently outside manufacturing in other functions integral to the firm. For example, a company's regulatory affairs specialist can liaise with a single regulatory body regarding a number of products simultaneously. These characteristics of equipment and labor contribute to internal scope economies.

Finally, whether scale and scope economies are external or internal, their cost-reducing impacts can be augmented if manufacturing benefits from learning curves - situations in which unit costs decline as cumulative experience grows along with cumulative output. ${ }^{21}$ These learning curve impacts may sustain the specialization and trade clusters originally formed by historical accidents.

\footnotetext{
20 Scherer and Ross [1990], op. cit., p. 100.

${ }^{21}$ For a discussion of manufacturing learning curves and their differences from scale economies, see, for example, Robert S. Pindyck and Daniel L. Rubinfeld, Microeconomics, $8^{\text {th }}$ edition, New York: Pearson Education Inc., 2013, pp. 261-265; and "Costs, Learning Curves and Scale Economies: From Simple to Multiple Regression”, chapter 3 in Ernst R. Berndt, The Practice of Econometrics: Classic and Contemporary, Reading, MA: Addison-Wesley Publishing Company, 1991, pp. 60-101.
} 


\section{II.D Are There Limits to Scale and Scope Economies?}

While scale economies result in lower unit costs and incentivize the manufacturing of greater output, to benefit from these cost-reducing scale economies, firms must be able to sell the increased output, which in turn may require firms to reach out to more distant customers, thereby increasing transportation and delivery costs and possibly offsetting scale-related manufacturing cost reductions. In the present context, transportation and delivery costs even over long distances are likely to be relatively negligible for chemically synthesized small molecule powders or solid generic drugs since they are light, solid, lack bulk and are mostly nonperishable. But distribution and transportation costs could be more important for more bulky injectable, liquid and non-oral drugs, and be quite significant for large molecules and temperature and light sensitive physician-administered injectable vaccines and biologic medicines, making it more attractive to locate plants near customers. ${ }^{22}$

Do other limits to scale and scope economies exist? The economic literature has generally concluded that in nearly all manufacturing and distribution operations, the realization of scale and scope economies is ultimately subject to diminishing returns. As a result, many industrial organization economists believe that the long-run average costs of industrial firms initially fall with increasing outputs due to economies of scale and scope, then are reasonably constant over a wide range of outputs as firms decentralize and implement other organizational

22 “Specialty Drugs, Pharmacies: A Growing Trend”, in Employee Benefit Plan Review, November 2001, 56(5):2224. 
changes, but ultimately increase with outputs as inevitable managerial diseconomies of scale emerge. ${ }^{23}$

\section{II.E Implications of Scale and Scope Economies for Industry Strategy and Public Policy}

For most consumer products, the existence of and prospects for realization of scale and scope economies has important implications for industry strategy, as well as for public policy toward industry.

For example, generally, economists believe firms face incentives to invest in capacity expansion when there are scale economies, for such investment will reduce unit costs and enable them to price competitively, assuming they can sell their expanded capacity output. Firms may also pursue rapid market share at lower current profits when they expect to realize learning curve benefits in the future. Public authorities may therefore protect domestic industries currently experiencing competitive challenges, subsidizing "infant industry" firms with favorable tax treatment and/or protecting them with tariffs, adopting import substitution policies in the hope that as a result imports will be reduced, exports will be increased, and prospects for domestic employment and a viable domestic manufacturing industry will be enhanced. ${ }^{24}$

Similarly, recognizing that because of historical accident certain geographical regions have nascent clusters of firms that are manufacturing biopharmaceutical products, public

\footnotetext{
23 On this, see, for example, Scherer and Ross [1990], op. cit., "What Checks the Realization of Scale Economies", pp. 102-106. The emergence of digitization-related manufacturing and distribution general purpose technologies, however, may have considerably expanded the region over which external and internal scale and scope economies are operative. But the role of digitization technologies is likely less prevalent in the biopharmaceutical than in the software, medical device and diagnostic industries.

${ }^{24}$ For a discussion of various international trade public policies, see Part 2, "International Trade Policy” in Krugman, Obstfeld and Melitz [2018], op. cit., chapters 9-12.
} 
authorities may seek to create environments conducive to generating external scale economies, such as providing job skill training and other educational opportunities, establishing tax-free manufacturing zones to attract further biopharmaceutical investments, and incentivizing complementary industries to locate nearby (e.g., chemical, boiler and vat equipment suppliers, providers of inventory storage facilities, and process engineering consulting firms).

For prescription drugs, where the safety, purity and efficacy of the product is not immediately discernable by consumers or payers and therefore must be assured by manufacturers, public policy in the form of regulation on the conduct of firms likely plays an even more prominent role in the geography of manufacturing these products. As we describe in some detail below, the onus on pharmaceutical companies to ensure the quality of prescription drugs intended for sale in the U.S. market likely places additional incentives on firms to identify economies of scale and scope related to satisfying these requirements. It might also guide U.S. policies to prefer the sourcing of drug products from some locations over others. For example, to the extent selling costs to other geographic jurisdictions are affected by import restrictions, tariffs, fees and regulatory submission requirements, the increased selling, distribution and transportation costs may offset declines in unit production costs from external or internal scale economies or from learning curves, and thereby constrain interregional trade.

\section{INDUSTRY AND PUBLIC POLICIES INCENTIVIZING PHARMACEUTICAL} MANUFACTURING IN FIVE GEOGRAPHIES

\section{III.A THE U.S. REGULATORY PROCESS TO MARKET GENERIC} PHARMACEUTICALS 
In the U.S., only prescription drugs and their base ingredients that are manufactured in accordance with basic quality manufacturing standards can be legally marketed by manufacturers whether domestic or internationally based. U.S. Federal law, as codified by regulations of the FDA, oversees the production and sale of prescription drugs in the U.S. These rules mandate that drugs to be sold in the U.S. must meet legal requirements for safety, and that they have the quality, purity, identity and strength that they are represented to possess. These rules are the result of longstanding efforts by the government and private parties to protect the American public from the consumption of potentially harmful substances. ${ }^{25,26}$

Manufacturing drugs typically involves several actions; all of these activities are regulated when the product is destined for U.S. sales and consumption. An initial set of steps involves making essential biochemical ingredients ("raw", "bulk" or "starting materials"), and creating "intermediates". In a second step, these bulk or intermediate materials are combined into a form that is biologically active but not readily consumable by patients (active pharmaceutical ingredients, or "APIs"). ${ }^{27}$ In the final step, the API is converted into consumable

\footnotetext{
${ }^{25}$ See https://www.fda.gov/media/73549/download

${ }^{26}$ The FDA explains the rationale for its central focus on protecting consumers from drugs that do not meet these standards on its webpage, titled "Promoting safe and effective drugs for 100 years', as follows: "At the turn of the $20^{\text {th }}$ century there were no federal regulations to protect the public from dangerous drugs. 'It was a menacing market.'....'Products ....were at minimum, useless remedies that picked the pocket of the user, but they could also be downright harmful.’” See https://www.fda.gov/about-fda/histories-product-regulation/promoting-safe-effectivedrugs-100-years

27 The U.S. Food and Drug Administration defines active pharmaceutical ingredient as "Any substance or mixture of substances intended to be used in the manufacture of a drug (medicinal) product and that, when used in the production of a drug, becomes an active ingredient of the drug product. Such substances are intended to furnish pharmacological activity or other direct effect in the diagnosis, cure, mitigation, treatment, or prevention of disease or to affect the structure or function of the body”. See U.S. FDA Drug Definitions, available online at https://www.registrarcorp.com/fda-drugs/definitions/.
} 
formulations (final dosage forms, "FDFs", e.g., tablets, capsules, ointments, also called "drug products”). ${ }^{28}$

To gain approval to market a new molecular entity in the U.S., the sponsor applicant must file a New Drug Application ("NDA”), a dossier containing extensive clinical trial evidence of safety and efficacy and documentation of compliance with Current Good Manufacturing Practice (cGMP) regulations, and obtain approval of the NDA from the FDA. ${ }^{29}$ cGMP regulations for drugs contain minimum requirements for the methods, facilities, and controls used in manufacturing, processing, and packing of a drug product. ${ }^{30}$ The regulations make sure that a product is safe for use, and that it has the ingredients and strength it claims to have. The approval process for new and generic drug marketing applications includes a review of the manufacturer's compliance with the cGMPs. FDA assessors and inspectors determine whether the firm has the necessary facilities, equipment, and ability to manufacture the drug it intends to market.

The requirements to obtain approval to market a generic drug in the U.S. are considerably less onerous than for an NDA. In particular, the generic sponsor’s Abbreviated New Drug

\footnotetext{
${ }^{28}$ Pursuant to 21 USCS § 379g (4), [Title 21. Food and Drugs; Chapter 9. Federal Food, Drug, and Cosmetic Act; General Authority; Fees; Fees Relating to Drugs] the term "final dosage form” means, "with respect to a prescription drug product, a finished dosage form which is approved for administration to a patient without substantial further manufacturing (such as capsules, tablets, or lyophilized products before reconstitution”. See Final Dosage Form Law and Legal Definition, available online at https://definitions.uslegal.com/f/final-dosageform/.

${ }^{29}$ FDA's portion of the Code of Federal Regulations (CFR) is in Title 21, which interprets the Federal Food, Drug and Cosmetic Act and related statutes, including the Public Health Service Act. The pharmaceutical or drug quality-related regulations appear in several parts of Title 21, including sections in parts 1-99, 200-299, 300-499, 600-799, and 800-1299. 21 CFR Part 314 and Part 600 entails the application and licensing submission requirements for new and generic drug applicants; 21 CFR Part 210 entails current Good Manufacturing Practice in Manufacturing Processing, packing, or Holding of Drugs; 21 CFR Part 211 entails current Good Manufacturing Practice for Finished Pharmaceuticals.

30 https://www.fda.gov/drugs/pharmaceutical-quality-resources/current-good-manufacturing-practice-cgmpregulations
} 
Application (ANDA) need not duplicate the clinical trial evidence regarding safety and efficacy, but instead needs only to provide evidence regarding its pharmaceutical and bioequivalence to the reference drug, as well as manufacturing in conformity with cGMP requirements. This requires the ANDA API or FDF sponsor to submit details regarding the chemistry, manufacturing and controls of a drug component. Components of a drug include the API or drug substance, excipients, and packaging material. When contained in a separate document, such information is called a Drug Master File ("DMF"). ${ }^{31}$ There is no legal or regulatory requirement to file a DMF. Information usually contained in a DMF can instead be provided in an NDA or ANDA.

Generic pharmaceutical companies can manufacture their bulk, API and/or FDF in-house, transfer it to a company affiliate, or outsource it to domestic or ex-U.S. facility contractors. After having obtained approval from the appropriate national health authorities, foreign generic companies can export API or FDF to a U.S. affiliate company, contract to sell API/FDF to generic companies in other countries, or can use their API or FDF for domestic sales of their own drug product. Traditionally, Europe-based API companies have focused on selling to branded companies in the U.S. and Western European markets because of the Europeans' proven capabilities to manufacture products meeting high quality standards. ${ }^{32}$

However, the industry trade press has noted that a changing trend is that far East Asian API companies are becoming major suppliers to the generic industry manufacturing drugs

\footnotetext{
${ }^{31}$ The information discussed in this paragraph and in the next paragraph is taken in large part from a 44-slide Powerpoint presentation by Arthur B. Shaw, Ph.D., FDA DMF Expert, FDA Small Business Office Webinar, Feb. 11, 2013, Drug Master Files Under GDUFA: DMF Basics, https://www.fda.gov/downloads/drugs/developmentapprovalprocess/...ucm339118.

32 Priyanka Bajpai, “The Changing API Industry”, BioSpectrum Asia Edition, 17 December 2018, page 3. Available online at https://www.biospectrumasia.com/opinion/33/12303/the-changing-api-industry.html.
} 
intended for consumption in Western markets. ${ }^{33}$ Based in part on the concern that foreign manufacturing sites were not being inspected as frequently and as thoroughly as U.S. API and FDF manufacturing sites, in 2012 Congress passed the Generic Drug User Fee Act (GDUFA) legislation, authorizing the FDA to collect application and annual fees from ANDA applicants and ANDA holders. The FDA committed that it would use some of the GDUFA user fee revenues to inspect foreign sites on a similar schedule to that of domestic sites. ${ }^{34}$

Based on data recently made public by the FDA, our prior research has documented that between 2013 and 2017, the vast majority (almost 90\%) of sites manufacturing API for pharmaceutical products intended for domestic U.S. consumption were located outside the U.S., and that a smaller majority (about 60\%) of FDF manufacturing sites were foreign, with both API and FDF facilities becoming increasingly foreign over time. ${ }^{35,} 36$ By 2017, the number of domestic FDF facilities was about two and one-half times larger than the number of domestic API facilities. However, between 2013 and 2017, the total number of manufacturing facilities (domestic plus foreign) registered to supply API and FDF to the U.S. market fell, with the U.S. shedding about 21-22\% of FDF and API facilities, foreign suppliers reducing their number of API facilities approximately half that much (about 10\%) and cutting their number of FDF facilities by a much smaller proportion, about $3 \%$. The larger proportionate reduction in API than FDF facilities, both domestic and foreign, may be the result of firms' attempting to capture scale and scope economies by increasing plant capacity, and for U.S. firms, exploiting comparative advantages by outsourcing generic drug manufacturing to foreign API and FDF suppliers. The results of this work suggests the domestic manufacturing of off-patent

\footnotetext{
33 Ibid., p. 4.

${ }^{34}$ For further discussion, see Ernst R. Berndt, Rena M. Conti and Stephen J. Murphy [2018], op. cit.

35 Ibid., p. 16.

${ }^{36}$ Ernst R. Berndt, Rena M. Conti and Stephen J. Murphy [2018], op. cit.
} 
prescription drugs includes primarily FDF rather than API activities, and that the growing vast majority of API generic drug manufacturing intended for U.S. consumption is now occurring abroad. ${ }^{37}$

In addition to mainland U.S., four regions - Puerto Rico, India, China and Ireland - have played historically or are playing currently important roles in the manufacturing of generic prescription drugs destined for U.S. consumption. In the remainder of this section, we briefly summarize particularly important public policies and industrial strategies historically adopted in these four currently prominent biopharmaceutical manufacturing geographies; more detailed narratives and references are presented in an Appendix. In all of these regions, historical industry strategy and public policy developments are likely associated with their prominence in the U.S. generic drug market. Interestingly, many of these roles appear malleable to changes in tax and industrial policy.

\section{III.B Puerto Rico}

For most of the late twentieth century, Puerto Rico was one of the major sources for the mainland U.S. pharmaceutical market, but since then Puerto Rico’s role as pharmaceutical supplier to the U.S. has diminished.

Puerto Rico’s role in the U.S. pharmaceutical market can be traced to targeted policies. In 1976, the U.S. Congress created special tax provisions to incentivize firms to locate manufacturing plants and bring medium to high-skilled jobs to Puerto Rico and other U.S. possessions. Also known as the Possession Tax Credit, Section 936, ${ }^{38}$ this legislation incentivized the location of pharmaceutical manufacturing in Puerto Rico by granting U.S.-based

\footnotetext{
37 Ibid., p. 18 of 67.

38 https://www.law.cornell.edu/uscode/text/26/936
} 
corporations a tax exemption on income earned in Puerto Rico. Subsidiaries of branded and generic companies could develop a drug in their U.S. research and development facilities, transfer the patent or proprietary technical knowledge to their wholly owned subsidiaries operating in Puerto Rico, and claim the income from the drugs as tax-free income. Many branded pharmaceutical, biotechnology, and medical device companies opened manufacturing plants in Puerto Rico. Generic pharmaceutical companies also located manufacturing plants in Puerto Rico.

Congress voted to phase out Section 936 in 1996, citing excessive cost and the very limited number of U.S. companies that received the tax break. In 2006, the phase-out was completed, resulting in plant closures and declining employment, and imposing an allegedly disproportionate tax burden on domestic Puerto Rican companies. Subsequently, the island's economy was damaged by passage of the U.S. Tax Cuts and Job Act of 2017, since it targeted income from "intangible" assets such as pharmaceuticals and medical devices, on which Puerto Rico has been heavily reliant. The Puerto Rican economy, including its pharmaceutical manufacturing industry, was then dealt a further blow in 2017 when the island was hit by the devastating Hurricane Maria.

\section{III.C India}

After gaining Independence in 1947, India pursued the goals of attaining national selfsufficiency in pharmaceutical manufacturing and providing its large population with access to low-priced medicines. Specifically, India pursued replacing product patent protection with process patent protection. A byproduct of this national import substitution policy was that India's scientific and technology-trained labor force learned how to reverse engineer imported patented medicines, a skill that became a unique comparative advantage. 
In an attempt to exploit further scale and scope economies by specializing in the export of pharmaceuticals, in 1995 India applied for membership in the World Trade Organization. To do so, in 2005 India needed to comply with the Agreement on Trade-Related Aspects of Intellectual Property Rights, which in turn required India to reintroduce intellectual property protection for product patents, and recognize both process and product patents for 20 years after issue, with some qualifications.

In the years that followed, India's fragmented pharmaceutical manufacturing industry has bIndia's export-oriented manufacturers have become more selective in launching FDF products abroad, focusing more on high margin specialized pharmaceuticals and biologics, and less on high volume but low margin small molecule oral solid medicines.

\section{III.D China}

As a legacy of China's pre-reform command economy, in the 1970s and 1980s numerous state-owned enterprises produced tablet dosage forms and distributed them to hospitals, their primary consumer. Governments or rural collectives took control of all funds, spent them, but had little incentive to monitor manufactured pharmaceuticals for safety and quality. Potential external and internal economies of scale and scope were not achieved. Most Chinese manufacturers were not capable of supplying pharmaceuticals to Western regulated markets, choosing instead to focus on the immense local patient populations. Many manufacturers relied on the repetitive production of low value-added bulk pharmaceuticals and imitation drugs and struggled to survive. In 2004, the Chinese State Food and Drug Administration ("SFDA") began an initiative to close down pharmaceutical manufacturers not able to comply with China's increasingly stringent current Good Manufacturing Practices requirements for products intended for domestic consumption. 
Attracted by China's comparative advantages in lower costs of manufacturing intermediate chemical goods, lower investment costs, shorter lead times and access to the immense Asian talent pool, in the last decade foreign pharmaceutical manufacturers have invested in the Chinese pharmaceutical industry. These investments were initially limited to the outsourcing of old products and commodity base ingredients involving less sophisticated chemistry. The Chinese bulk drugs market has evolved rapidly over the years, and today it is large and diversified with about 7,000 base ingredient manufacturers.

Also plaguing Chinese manufacturing of pharmaceutical products are major issues in intellectual property rights protection enforcement. This has resulted in a low level of market protection for domestic branded drugs and allowed established foreign generics and off-patent brands to dominate the domestic market. It is estimated that $80 \%$ of counterfeit products in China are consumed in rural areas. Moreover, although China officially seeks to move up the value chain from manufacturing bulk chemicals and intermediate products to producing and exporting finished drugs, the relatively hefty facility and application fees associated with the 2013 implementation of the U.S.' Generic Drug User Fee Act may be sufficiently prohibitive to limit the number of Chinese companies focusing on pursuing the finished drug U.S. market, instead preferring to invest in the rapidly growing and less regulated domestic Chinese market. ${ }^{39}$

\section{III.E. Ireland}

Similar in some respects to Puerto Rico in previous eras but unlike India and China, in Ireland public policies have primarily used corporate tax provisions to incentivize foreign firms to establish their nominal headquarters in Ireland, even if the multinational firms' de facto operations are managed abroad. Outside Ireland, these tax policies are said to incentivize tax

\footnotetext{
${ }^{39}$ Shannon Bennett, “China’s growing presence in the global supply chain”, Chemistry Today, January/February 2012, 30(1), p. 1 of 3.
} 
inversions. U.S.-controlled firms represent almost all foreign firms in Ireland. Academic research has ranked Ireland as the world's largest tax haven, even larger than the entire Caribbean tax haven system. However, beginning in 2017 and continuing thereafter, U.S. and U.K. tax policy countermeasures to stem the flow of Irish tax inversions may have the effect of mitigating the locating of drug manufacturing in Ireland. ${ }^{40}$

The ways by which Irish tax authorities define the base income and profits on which corporate taxes are assessed (called the base erosion and profit sharing - "BEPS" tools) involve how depreciation on intangible assets such as intellectual property ("IP”) is treated, and likely indirectly affect incentives for pharmaceutical firms to locate their manufacturing to Ireland. Ireland's main BEPS tools use IP to effect the profit shift from higher-tax jurisdictions to Ireland via royalty payment schemes. To avoid paying Irish corporate taxes on these shifted profits, the BEP tools either transfer the profits to traditional tax havens having explicit $0 \%$ corporate tax rates (with Ireland having bilateral tax treaties with more than 70 countries) via royalty payment schemes, or use intangible capital allowance schemes to write-off the profits against Irish tax. Not surprisingly, most U.S. multinationals in Ireland operate in the two largest Irish industries where IP plays a prominent role --- technology (including software) and the life sciences. Whereas Ireland's nominal "headline” corporate tax rate is $12.5 \%$, Irelands BEPS tools reduce Irish tax liabilities to an effective tax rate of $0 \%$ to $2.5 \%$, depending on which BEPS tool is used. By comparison, the average 2001-2006 effective corporate tax rate on pharmaceuticals in the U.S. was $31.5 \%$.

\footnotetext{
40 Wikipedia, “Corporation tax in the Republic of Ireland”, last updated June 17, 2019, p. 1, 12,13,25-29 of 55. Available online at

https://en.wikipedia.org/w/index.php?title=Corporation_tax_in_the_Republic_of_Ireland
} 
The indirect effect of BEPS tools on incentivizing drug manufacturing in Ireland arises through the tools' emphasis on job creation (either of Irish employees or of foreign employees to Ireland). To be eligible to utilize the Irish BEPS tools and their effective tax rates of $0 \%$ to 2.5\%, multinationals must meet conditions that document and prove a nexus between the IP and the BEPS tools they implement, such as carrying out a "relevant trade" on the IP in Ireland (e.g., manufacturing a patented products), and documenting the level of Irish employment engaged in the "relevant activities" on the IP. Pharmaceutical companies such as Actavis, Allergan, Endo, Pfizer, Mallinckrodt, Perrigo, Alkermes, Shire and Horizon either succeeded or at least attempted to engage in corporate tax inversions. According to one source, since 2008 the pharmaceutical industry has invested close to $€ 10$ billion in manufacturing and research and development in Ireland.

With these public policies and industry strategies as background, we now move on to a discussion of our research findings regarding the changing geography of pharmaceuticals intended for consumption in the U.S., beginning with a brief summary of old and new data sources.

\section{NEW DATA FROM THE U.S. FOOD AND DRUG ADMINISTRATION}

The data underlying our previous research on the changing U.S. and ex-U.S. shares of API and FDF manufacturing sites for drugs intended for U.S. consumption was based on data supplied to the FDA by manufacturers through the FDA's self-identification program, and then published as site counts by the FDA. The identities of the sites were not available, and the only brovided to the FDA by manufacturers, but derive from a different related data source, the list of firms participating in the FDA's Generic Drug User Fee Act ("GDUFA") program. ${ }^{41}$ FDA

\footnotetext{
${ }^{41}$ These two data sources are discussed in Berndt, Conti and Murphy [2018], op. cit.
} 
officials have informed us that the count and identity of manufacturing sites in the two data sources do not always agree. Since the GDUFA list is accompanied by manufacturers' actual GDUFA payments, for purposes of identifying the location of generic drug API and FDF manufacturing facilities, we consider it more reliable than the voluntary self-identification list. ${ }^{42}$

The new data extend our previous research in two directions. First, whereas our earlier research covered the first five fiscal years of the initial Generic Drug User Fee Program (denoted GDUFA-I) covering fiscal years 2013-2017, the new data add the first two years of the renewed user fee program (denoted GDUFA-II), 2018 and 2019, and also provide an alternative count of API and FDF sites during the 2013-2017 GDUFA-I era. Second, in the data used in our previous research, we only had information on the counts of API and FDF manufacturing sites U.S. and ex-U.S., but had no information on its address. The new data list both the name of the organization remitting the GDUFA fees to the FDA (fees that differ depending on whether it is an API or FDF site), and the detailed address of the manufacturing site (but not necessarily the address of organization remitting the user fee). However, the data do not disclose what molecule formulations are manufactured at the API or FDF site, nor their volumes or value. In addition, no information is available concerning the corporate ownership of the API or FDF site, or the ANDA or DMF number under which API or FDF manufacturing is approved for that site.

In terms of geography, we combine data from various countries in the FDA data base into three global regions: (i) the Americas - U.S., Canada, Mexico, Argentina and Other Americas; (ii) Europe - France, Germany, Italy, Great Britain, Ireland, Rest of Eastern Europe and Rest of Western Europe; and (iii) Asia and Rest of World - India, China, Israel, Taiwan and Rest of

\footnotetext{
${ }^{42}$ We are indebted to Andreas Schick and Qiyu Liu from the FDA for making this data available to us in Excel files.
} 
World. For each of these three global regions, we also provide site counts annually for each of the component countries. For the U.S., we utilize the FDA's definition of 19 regions, with the states/districts/territories in each FDA region following FDA conventions. The states included in each of the 19 FDA U.S. regions are listed in notes to Tables 3 and $4 .{ }^{43}$ We also combine the 19 FDA regions into four aggregated domestic geographic areas: Southeast (ATL, FLA, NOL, SJN), Other East (BLT, NWE, NWJ, NYK, PHI), Central (CHI, CIN, DAL, DET, KAN, MIN), FDF manufacturing sites, comparing and updating findings based on the new FDA data with those published in our prior research. Next, we disaggregate the ex-U.S. data geographically into three global regions and their component countries. Then, we disaggregate the U.S. domestic data into the 19 FDA regions and four geographic areas. Finally, we discuss limitations and caveats to our FDA data and analyses. Most notably, the results we present here are simply counts of sites, and do not weight by quantities produced at these sites. We do not have data on quantities of the drugs produced at these sites and as far as we are aware the FDA does not have quantity data. ${ }^{44}$

\section{VI.A U.S. and ex-U.S. Generic Drug Manufacturing Site Counts: Comparisons With and Updates to Previous Research}

In Table 1 we report the number and share of API manufacturing facilities by global region, annually 2013 through 2019, as recorded in the FDA's GDUFA facility payments files.

\footnotetext{
43 The FDA defines its regions as follows: ATL (Georgia, North Carolina, South Carolina); BLT (Maryland, District of Columbia); CHI (Illinois); CIN (Kentucky, Ohio); DAL (Arkansas, Oklahoma, Texas); DEN (Colorado, New Mexico, Utah, Wyoming); DET (Indiana, Michigan); FLA (Florida); KAN (Iowa, Kansas, Missouri, Nebraska); LOS (Arizona, Southern California); MIN (Minnesota, North Dakota, South Dakota, Wisconsin); NWE (Connecticut, Maine, Massachusetts, New Hampshire, Rhode Island, Vermont); NWJ (New Jersey); NOL

(Alabama, Louisiana, Mississippi, Tennessee); NYK (New York); PHI (Delaware, Pennsylvania); SAN (Northern California, Hawaii, Nevada); SJN (Puerto Rico, US Virgin Islands); SEA (Alaska, Idaho, Montana, Oregon, Washington). The list of states covered by each of the 19 FDA US regions is taken from https://www.fda.gov/about$\underline{\mathrm{fda} / \text { contact-ora/ora-dis trict-directors. }}$

${ }^{44}$ https://www.fda.gov/drugs/drug-shortages/report-drug-shortages-root-causes-and-potential-solutions
} 
In Table 2 we report the corresponding regional number and share of global FDF manufacturing facility sites. Our previously reported research was based instead on voluntary self-identification program files. Comparisons of number of U.S. and ex-U.S. manufacturing facilities in the overlapping 2013-2017 years reveals that the number of API and FDF sites in Tables 1 and 2 below is generally slightly greater than those reported in Table 2 of our previously published research, although time trends are similar. ${ }^{45}$ Apparently the FDA can identify more sites using data on actual payment of mandated GDUFA fees than by relying on its voluntary selfidentification programs.

For API sites, as seen in the bottom rows of the left panel of columns in Table 1, over the 2013-2019 time period the number of U.S. API facilities has been falling in all years except 2014; by 2019 at 118 the number of API sites is about 10\% smaller than the 131 sites in 2013 .

The total number of ex-U.S. API sites has also been falling in all years except 2014, from 792 in 2013 to 762 in 2019 - a decline of about $4 \%$, smaller than for the number of U.S. API sites. ${ }^{46}$ Globally, the decline in the number of facilities producing API intended for the U.S. market has declined by just under $5 \%$. As seen in the corresponding bottom rows of the right panel of Table 1, the U.S. share of global API sites has fallen very slightly from $14.19 \%$ in 2013 to $13.41 \%$ in 2019, while the ex-U.S. share has grown correspondingly.

Trends in the global location of FDF manufacturing differ considerably from those for API, as seen in the bottom rows of in the left panel of Table 2. Specifically, although vacillating slightly between adjacent years, the number of U.S. FDF facilities has remained unchanged at

\footnotetext{
45 See Table 2 on page 17 of 67 in Berndt, Conti and Murphy [2018], op. cit.

${ }^{46}$ The anomalous 2014 increase in U.S. and ex-U.S. API sites could reflect that fact that the FDA changed its ANDA filing specifications from requiring single exhibit batch stability data to three exhibit stability data, effective for all ANDA filings after July 2014, thereby creating a temporary pre-July 2014 surge. See IQVIA Institute for Human Data Science, U.S. Generics Market -- Evolution of Indian Players, February 2019, p. 4.
} 
288 between 2013 and 2019, while the number of ex-U.S. FDF facility sites increased about 12\% from 386 in 2013 to 433 in 2019. Thus, as seen in the bottom rows of the right panel in Table 2, the U.S. share of global FDF facilities fell from 42.73\% in 2013 to 39.94\% in 2019, whereas the ex-U.S. share increased from $57.27 \%$ to $60.06 \%$. While the U.S. share of global FDF facility sites is about three times larger than the U.S. share of API facility sites (about $42 \%$ vs. $14 \%$ ), the U.S. FDF share has been falling more rapidly than the U.S. API share.

In summary, for both API and FDF, the majority of sites manufacturing pharmaceuticals intended for the U.S. market are sourced ex-U.S. Prescription pharmaceuticals are generally not manufactured in America, although the U.S. share is larger for FDF than API sites. These 20132019 U.S. and ex-U.S. trends essentially continue the 2013-2017 trends reported in our previous research.

VI.B. Decomposition of ex-U.S. Generic Manufacturing Sites into National and Global Regional Location Counts

Entirely new research findings presented in Tables 1 and 2 concern the national and regional composition of global API and FDF manufacturing facilities. As seen in Table 1, over the entire 2013-2019 time frame, both India and China had more API sites than did the U.S.; while the U.S. averaged about 125 API sites (about 14\% of all global API sites), India averaged almost twice that (238, about 26\%) and China about 30\% more than the U.S. (164, about $18 \%$ of global total).

In terms of trends, the number of API sites in India was relatively stable 2013-2017, then increased slightly in 2018 and 2019. The number of API sites in China grew 2013-2016, peaked in 2016, and then fell substantially. India appears to have specialized in API manufacturing more than China, although both countries extensively export API to the U.S. When summed 
over India and China, between 2013 and 2019 their combined share of global API sites increased from $42.37 \%$ to $45.12 \%$. In comparison, U.S. dependence on API imports from sites in other countries with whom international trade negotiations are currently or could soon be underway -Great Britain, Ireland, Canada and Mexico - are very modest relative to India and China.

The number and shares of FDF sites in India and China relative to those in the U.S. are very different from API facilities (see Table 2). Although growing in numbers and shares over time, FDF sites in India averaged about 150 (21\%) over the 2013-2019 time period, slightly more than half those in the U.S., the latter remaining constant at just under 290 (about $40 \%$ of global). While the Chinese share of global API sites was falling from 19\% in 2016 to $17 \%$ in 2019, the Chinese share of global FDF sites was smaller but increasing steadily, from five to eight percent between 2013 and 2019. India's portfolio of API and FDF sites is larger and more balanced than that of China, but the smaller FDF share in China is growing very rapidly. China appears to be moving into higher-valued FDF production, and away from the more commoditylike API manufacturing. India is also increasing its number of FDF sites, with its API site numbers reflecting stability. As the share of FDF sites is increasing in India and China, it is falling in the U.S., but is stable in Europe.

For both API and FDF, the three countries with the largest number of facility sites are the U.S., India and China. Several countries that together comprise the rest of Western Europe have the fourth largest number of both API and FDF sites at about 90 (10\%) and 50 (7\%), respectively. The fifth largest API country is Italy (70, just under 8\%) while the fifth largest FDF nation is Germany (about 23, 4\% of global). In terms of the British Isles, Great Britain (comprised of England, Scotland and Wales) has about twice as many API sites as Ireland (15 vs. 7), and a slightly greater number of FDF sites (8 vs. 6), with neither displaying a clear trend over 
time. There are twice as many FDF sites in Canada as API facilities, while the number of FDF sites in Mexico is very small (three or four). Very few FDF sites in the Brexit-related countries (Great Britain and Ireland) export to the U.S. - between five and seven sites.

In summary, currently a substantial share of API and FDF sites in India and China are sources for generic drugs intended for U.S. consumption. By comparison, the number of API and FDF sites in Canada and Mexico, and in the Brexit-related countries - Great Britain and Ireland - is rather limited.

\section{VI.C Evidence on the Location of Domestic Manufacturing Sites}

The number and share of domestic API facilities, annually 2013-2019, by FDA region are reported in Table 3, while the corresponding number and regional shares of domestic FDF totals are presented in Table 4 .

In terms of sheer size, throughout the 2013 - 2019 time period, the Central region had the largest number of API sites, while the West region had the smallest number (Table 3). By 2019, at 59, the eastern half of the country (Southeast plus Other East) had exactly the same number of API facilities as did the western half of the U.S. (Central plus West). For FDF facilities (Table 4), at about $60 \%$ the eastern half of the country (Southeast plus Other East) dominates the western half (Central plus West). Among FDFs, the Other East region had the largest number of facilities, while the West had the smallest number.

The burden of the 2013-2019 decline in the total number of U.S. API sites (the first panel in Table 3) was borne entirely by two regions - the Central region that lost ten sites, and the Southeast region that lost nine. Within the Central region, the local "losers" were DAL (Arkansas, Oklahoma and Texas) who lost four sites, DET (Indiana, Michigan) losing three sites, MIN (Minnesota, North Dakota, South Dakota and Wisconsin) losing two sites, and KAN (Iowa, 
Kansas, Missouri and Nebraska) who lost one API site. There were no "winners" within the Central region.

Local API "losers" within the Southeast region included SJN (Puerto Rico and the U.S. Virgin Islands) that declined sharply from six API sites in 2013 to only one in 2019, NOL (Alabama, Louisiana, Mississippi and Tennessee) who lost four sites (from nine to five), and ATL (Georgia, North Carolina and South Carolina) who remained the largest local region within Southeast but lost one API facility - declining from 15 in 2013 to 14 in 2019. FLA (Florida) was the lone "winner" in the Southeast region, increasing from zero API sites in 2013 to one in 2019. Notably, while the API "losers" were for the most part regions of the U.S. experiencing the fastest overall population growth, they were also those most subject to supply interruptions from severe weather storms. Perhaps not surprisingly given our discussion of law changes above, Puerto Rico is also noted to be a loser of manufacturing sites.

The U.S. total number of FDF sites at 288 was unchanged between 2013 and 2019, but this masked a changing domestic production composition (Table 4). As with the number of APIs, the Southeast region was the largest "loser" in number of FDF sites, falling 12\% from 66 FDF sites in 2013 to 58 facilities in 2019. Within the Southeast, FLA (Florida) took the largest hit, falling from 19 to ten sites between 2013 and 2019, while NOL (Alabama, Louisiana, Mississippi and Tennessee) declined from nine to six. ATL (Georgia, North Carolina and South Carolina) retained its position as the largest local region within the Southeast, increasing the number of FDF sites from 29 to 31 in 2013-2019. Defying the expected impacts of the repeal of the pharmaceutical friendly Section 936 tax provision, in the SJN region (Puerto Rico plus the U.S. Virgin Islands) the number of FDF sites actually increased, from nine in 2013 to eleven in 2019, but only after falling from a peak of fifteen in 2016. 
The three other large U.S. regions (Other East, Central and West) offset declines in the number of FDF facilities in the Southeast, with the Central region increasing in number from 70 to 74 FDF sites, the West from 36 to 39 FDF facilities, and the most populous Other East region increasing by but one facility, from 116 to 117 between 2013 and 2019, albeit experiencing both increases and decreases in adjacent years during the 2013-2019 time frame. Within the Central region, the FDF “winners” were KAN (Iowa, Kansas, Missouri and Nebraska) who increased from nine to twelve facilities, and MIN (Minnesota, North Dakota, South Dakota and Wisconsin) from five to eight sites. Within the West region, the largest local FDF "winner" was DEN (Colorado, New Mexico, Utah and Wyoming) that increased from eleven to fourteen facility sites. The most populous local region within the West - LOS (Arizona and Southern California) actually lost one FDF site, falling from 24 in 2013 to 23 in 2019.

In summary, declines in API and FDF site numbers have been disproportionately large in weather storm-sensitive and "Rust belt" states, and in the case of FDF sites, perhaps surprisingly small in Puerto Rico. Specifically, the number of API manufacturing facilities operating in the U.S. has been declining since 2013, with the decrease being particularly evident in the weather sensitive Southeast (Puerto Rico and the US Virgin Islands, and Georgia, North Carolina and South Carolina), the "Rust Belt" states (Indiana, Michigan) and weather sensitive (Arkansas, Oklahoma and Texas) portions of the Central region. Although it is the Southeast that has also borne the greatest loss of FDF facilities, within the Southeast it is FLA (Florida) and not SJN (Puerto Rico and the U.S. Virgin Islands) that has experienced the brunt of the loss in FDF manufacturing activities. Other regions of the U.S. (Central, West and Other East) have increased their number of active FDF manufacturing facilities. Moreover, the manufacturing 
trajectories of API in the U.S. differ considerably from those for FDF, with the former in aggregate decline and the latter in aggregate being relatively stable.

\section{VI.D. Limitations to FDA Data and Caveats to our Analyses}

There are a number of important limitations to the research reported here. Among the data limitations, it is particularly important to recognize that while we utilize annual 2013-2019 FDA data on the number of API and FDF manufacturing sites by geography, we have no information regarding the volumes or dollar values of pharmaceuticals produced at those sites, the identities of molecules produced, the formulation types manufactured at the sites (oral, injectable/infusible or other), or corporate ownership relationships among the sites. Moreover, since our annual data begin in 2013, we are unable to examine perhaps much larger trend changes in the geography of pharmaceutical manufacturing that predate $2013 .{ }^{47}$ Our data emanate from the Generic Drug User Fee payment files at the FDA, and are therefore confined to the manufacturing of prescription pharmaceutical generic drugs intended for consumption in the U.S. We do not have information on the manufacturing location of branded, non-generic drugs, nor on over-the-counter non-prescription formulations.

In addition to these data limitations, while our findings document changing trends in the location of API and FDF manufacturing facilities based on data newly available from the FDA,

\footnotetext{
${ }^{47}$ Substantial changes in the ex-US geographic sources of imported active pharmaceutical ingredients appear to have occurred in the three years prior to 2013, the beginning of our study period. For example, a 2011 survey conducted by the US Department of Commerce of domestic pharmaceutical manufacturers and their reliance on non-US suppliers of active pharmaceutical ingredients concluded that in 2010 the top five countries supplying the US were Italy, India, Germany, China and France (actually, Puerto Rico was first, with the study considering Puerto Rico as being "outside the United States"); within the continental US, pharmaceutical manufacturing facilities were concentrated in California, New York, North Carolina and Ohio. See U.S. Department of Commerce, Bureau of Industry and Security, Office of Technology Evaluation, Reliance on Foreign Sourcing in the Healthcare and Public Health (HPH) Sector: Pharmaceuticals, Medical Devices and Surgical Equipment, Washington DC, December 2011, pages 5, 23 and 35 of 107. Available online at https://www.hida.org/App Themes/Member/docs/GA/Industry-Issues/Emergency-Pandemic/Dept-CommerceStudy Healthcare-Foreign-Sourcing.pdf.
} 
these data are unable to inform reasons and factors underlying those trends. In Section III above we have summarized historical industry strategy and public policy developments in four prominent manufacturing geographies that likely are associated with these trends; in the Appendix to this manuscript we present a more detailed narrative of these developments, and provide references. Future work meriting a high priority would empirically investigate the levels and trends we describe in the results and link them more directly to the effects of firms aiming to capture internal scale and scope economies in manufacturing, gains from tax rules, attempts to reduce GDUFA-related user fees, and/or a number of other factors such as more intense monitoring of compliance with cGMP standards by various regulatory authorities discussed in Section III briefly and in more depth in the Appendix.

\section{SUMMARY OF FINDINGS AND IMPLICATIONS}

The goal of this research has been to document the changing geography of generic drug manufacturing between 2013 and 2019 among those pharmaceuticals intended to be consumed in the U.S.

What we find is that even in an era where the number of generic drug prescriptions dispensed in the U.S. grew by about $15 \%,{ }^{48}$ the global total number of API sites fell by about $5 \%$ and the global total of FDF sites increased by just over 5\%. This suggests that generic manufacturing plant sites have been expanding their capacities and achieving scale economies.

Moreover, API intended for the U.S. market is overwhelmingly manufactured ex-U.S. The ex-U.S. share has been relatively stable at about $87 \%$, with the ex-US API sources dominated by India (about 26\% of global) and China (18\%). When summed over India and China, their combined share increased from about $42 \%$ to $45 \%$. Meanwhile, API shares for the

\footnotetext{
${ }^{48}$ IQVIA Institute for Human Data Science [2018], op. cit., pp. 10-14.
} 
$4^{\text {th }}$ and $5^{\text {th }}$ ranked countries - Italy and Germany -- fell slightly to about $8 \%$ and $4 \%$, respectively.

In terms of FDF production, unlike for API the U.S. is still the largest supply source (averaging about $41 \%$ of global sites), India is second (growing to about 21\%), while China is third (with share growing from 5\% to 8\%). As the share of global FDF sites has increased in India and China, it fell slightly in the U.S., but was stable in Europe where Germany and Italy have a combined share of about $6 \%$.

Within the U.S., the total number of API sites declined by about $10 \%$ between 2013 and 2019, with the decline borne entirely by two FDA regions - the Central region that lost ten sites (four in DAL and three in DET) and the Southeast region that lost nine (with five being in SJN and four in NOL). Thus, API "losers" in the U.S. were regions vulnerable to supply interruptions from severe weather and the "Rust Belt" states.

Although the total number of FDF sites in the U.S. was unchanged between 2013 and 2019, the Southeast region lost the most share, particularly FLA and NOL, even as the Carolinas and George experienced a slight increase, and SJN vacillated, growing in 2013-2016, but then falling to 2019 after Hurricane Maria.

Because of the U.S.' substantial reliance on imported API and FDF from India and China, current bilateral international trade negotiations with either of them and between them could have a material impact on domestic prices of generic drugs. ${ }^{49}$ By comparison, the very

\footnotetext{
${ }^{49}$ Subhadip Sircar and Shruti Srivastata, "India Increases Tariffs on U.S. Goods as Trade War Heats Up", Bloomberg News, June 16, 2019. Available online at https://www.bloomberg.com/news/articles/2019-06-16/ india-imposes-tariffs-on-u-s-goods-as-global-trade-war-heats-up; Yanzhong Huang, "U.S. Dependence on Pharmaceutical Products from China”, Council on Foreign Relations Blog Post, August 14, 2019. Available online at https://www.cfr.org/blog/us-dependence-pharmaceutical-products-china. "China's new drug law may open door for Indian generic medicines: Report”, The Economic Times, August 27, 2019. Available online at https://economictimes.indiatimes.com/industry/healthcare/biotech/pharmaceuticals/chinas-new-drug-law-mayopen-door-for-indian-generic-medicines-report/articleshow/70864639.cms
} 
limited imports from the UK, Ireland, Mexico and Canada suggest that the Brexit and U.S.Mexico-Canada trade negotiations will have at most modest impacts on domestic generic drug prices. ${ }^{50}$ Military engagements could also impact domestic availability of generic drugs, but currently few Russian and Mideastern sites import API and FDF into the U.S., although U.S. dependence on Chinese manufacturing of antibiotics is substantial. ${ }^{51}$ Global climate change patterns and severe weather events such as flooding could potentially affect pharmaceutical supplies. Within the U.S. we find there has been a substantial reduction in the number of API and FDF sites in severe weather vulnerable regions such as the Southeast and Central U.S.

The implications of our research regarding the U.S.' dependence and potential vulnerability to foreign pharmaceutical supplies highlights a significant data limitation of this research, a limitation that has also been exposed as the FDA has sought to deal with drug shortages over the last decade: We simply do not know, as one researcher stated, "Who Makes This Drug?”52 Because of the increasingly common industry practice of outsourcing manufacturing to contract manufacturing organizations and the failure of firms promptly to notify the FDA or the public of product quality issues and product discontinuation, according to this researcher,

“Even FDA can't easily determine whether a drug is made by the ANDA sponsor or a contract manufacturer...FDA maintains records that identify which manufacturers are producing generic drugs for the US market. However, these data aren't maintained in a format that makes it possible for the agency to quickly distinguish between ANDA holders and contract manufacturers of fill and finish products or base ingredients. These records aren't available for public scrutiny.... The agency generally treats non-public business relationships as confidential commercial or financial information, exempting it from public disclosure."53

\footnotetext{
${ }^{50}$ Eric Palmer, "PCI Pharma Services takes steps to prepare for Brexit”, FiercePharma, August 28, 2019. Available online at https://www.fiercepharma.com/manufacturing/pci-pharma-services-takes-steps-to-prepare-...

${ }^{51}$ Huang [2019], op. cit.

52 Rena M. Conti, “Who Makes This Drug?”, The Cancer Letter, 40(1), January 3, 2014. Available from www.cancerletter.com.

${ }^{53}$ Ibid., pp. 3-4 of 14.
} 
Although the API and FDF manufacturing site data made available to us by the FDA identify the address of the site and the organization paying the Generic Drug User Fee, no information is available identifying the products actually manufactured at the site nor their volumes. As the FDA's Drug Shortage Task Force simply stated, 'FDA's data do not capture how much of a drug is produced at each manufacturing facility." 54 Even the FDA data revealing results of FDA manufacturing site inspections "does not list the products being made at the facilities”. ${ }^{55}$ According to the FDA, “...the pharmaceutical industry regards the location of their manufacturing facilities as confidential commercial information and claim that keeping this information private is a matter of supply security, e.g. to prevent theft or diversion attempts." 56

Moreover, many generic drugs whose ANDA has been FDA approved are not marketed. For example, as the FDA acknowledged in its Task Force study of Drug Shortages, "FDA analysis shows that as of June 2019, for all generic drugs with approved applications, 39 percent were observed to be marketed, and the remaining 61 percent were approved but not marketed."57

The phenomenon of FDA-approved generic drugs not actually being marketed is occurring even for the FDA's prioritized "first generics" - those drugs approved by the FDA as the first competitor to a brand that has lost marketing exclusivity, and considered by the FDA to be a public health priority bringing new competition and savings. A 2019 study published by the Association for Accessible Medicines - the U.S.' generic drug trade association - concluded

\footnotetext{
54 U.S. Food and Drug Administration, Drug Shortages: Root Causes and Potential Solutions-A Report by the Drug Shortages Task Force, October 2019, p. 118, footnote 19.

55 Ibid., p. 28, footnote 18.

${ }^{56}$ Ibid., p. 45

${ }^{57}$ Ibid., pp. 31-32. Notably, these non-marketed data "exclude products for which all applications are listed in the discontinued section of Orange Book, as they have effectively left the market and are no longer available.” (footnote 29, p. 32).
} 
that "...fewer than half of the first generics approved by FDA since 2016 are commercially available to patients". 58

In summary, while we believe this research contributes substantively to our understanding of where in the globe generic drug API and FDF manufacturing facilities are located and how that is changing, a major gap in our knowledge meriting high research priority awaits data availability linking site locations to products actually being manufactured, and their volumes. We leave it to future empirical work to further empirically investigate the associative and causal relationships between country-specific policies and drug manufacturing location. Another illuminating empirical exercise would be to undertake a similar descriptive examination of drug manufacturing among products destined for European Union consumption.

${ }^{58}$ Access Denied: Why New Generics Are Not Reaching America's Seniors, Association for Accessible Medicines, 2019. 
Table 1 - Number and Share of FDA API Facility Sites by Global Region, Annually, 2013-2019

\begin{tabular}{|c|c|c|c|c|c|c|c|c|c|c|c|c|c|c|}
\hline \multirow[b]{2}{*}{ Global Regions } & \multicolumn{7}{|c|}{ Number of API Facilities by Global Regions } & \multicolumn{7}{|c|}{ Share of API Facilities by Global Regions } \\
\hline & 2013 & 2014 & 2015 & 2016 & 2017 & 2018 & 2019 & 2013 & 2014 & 2015 & 2016 & 2017 & 2018 & 2019 \\
\hline \multicolumn{15}{|l|}{ Americas } \\
\hline USA & 131 & 137 & 124 & 123 & 116 & 120 & 118 & 14.19 & 14.44 & 13.38 & 13.47 & 12.89 & 13.26 & 13.41 \\
\hline CAN & 15 & 16 & 16 & 17 & 16 & 17 & 13 & 1.63 & 1.69 & 1.73 & 1.86 & 1.78 & 1.88 & 1.48 \\
\hline MEX & 11 & 12 & 10 & 11 & 13 & 12 & 10 & 1.19 & 1.26 & 1.08 & 1.2 & 1.44 & 1.33 & 1.14 \\
\hline ARG & 5 & 5 & 5 & 4 & 5 & 5 & 5 & 0.54 & 0.53 & 0.54 & 0.44 & 0.56 & 0.55 & 0.57 \\
\hline Other & 5 & 5 & 5 & 5 & 6 & 6 & 5 & 0.54 & 0.53 & 0.54 & 0.55 & 0.67 & 0.66 & 0.57 \\
\hline Sub-total & 167 & 175 & 160 & 160 & 156 & 160 & 151 & 18.09 & 18.44 & 17.26 & 17.52 & 17.33 & 17.68 & 17.16 \\
\hline \multicolumn{15}{|l|}{ Europe } \\
\hline FRA & 29 & 30 & 28 & 26 & 24 & 26 & 23 & 3.14 & 3.16 & 3.02 & 2.85 & 2.67 & 2.87 & 2.61 \\
\hline GER & 37 & 40 & 38 & 37 & 36 & 34 & 33 & 4.01 & 4.21 & 4.1 & 4.05 & 4 & 3.76 & 3.75 \\
\hline ITA & 73 & 71 & 68 & 67 & 67 & 70 & 66 & 7.91 & 7.48 & 7.34 & 7.34 & 7.44 & 7.73 & 7.5 \\
\hline GBR & 16 & 16 & 16 & 16 & 14 & 14 & 15 & 1.73 & 1.69 & 1.73 & 1.75 & 1.56 & 1.55 & 1.7 \\
\hline IRL & 6 & 6 & 7 & 7 & 7 & 5 & 7 & 0.65 & 0.63 & 0.76 & 0.77 & 0.78 & 0.55 & 0.8 \\
\hline Rest - Eastern & 33 & 29 & 34 & 33 & 31 & 30 & 29 & 3.58 & 3.06 & 3.67 & 3.61 & 3.44 & 3.31 & 3.3 \\
\hline Rest - Western & 95 & 101 & 92 & 90 & 89 & 92 & 91 & 10.29 & 10.64 & 9.92 & 9.86 & 9.89 & 10.17 & 10.34 \\
\hline Sub-total & 289 & 293 & 283 & 276 & 268 & 271 & 264 & 31.31 & 30.87 & 30.53 & 30.23 & 29.78 & 29.94 & 30 \\
\hline \multicolumn{15}{|l|}{ Asia Rest - World } \\
\hline IND & 232 & 238 & 235 & 231 & 238 & 244 & 249 & 25.14 & 25.08 & 25.35 & 25.3 & 26.44 & 26.96 & 28.3 \\
\hline $\mathrm{CHN}$ & 159 & 167 & 170 & 174 & 169 & 159 & 148 & 17.23 & 17.6 & 18.34 & 19.06 & 18.78 & 17.57 & 16.82 \\
\hline ISR & 19 & 18 & 18 & 16 & 15 & 8 & 7 & 2.06 & 1.9 & 1.94 & 1.75 & 1.67 & 0.88 & 0.8 \\
\hline TWN & 7 & 8 & 8 & 8 & 8 & 15 & 16 & 0.76 & 0.84 & 0.86 & 0.88 & 0.89 & 1.66 & 1.82 \\
\hline Rest - World & 50 & 50 & 53 & 48 & 46 & 48 & 45 & 5.42 & 5.27 & 5.72 & 5.26 & 5.11 & 5.3 & 5.11 \\
\hline Sub-total & 467 & 481 & 484 & 477 & 476 & 474 & 465 & 50.6 & 50.68 & 52.21 & 52.25 & 52.89 & 52.38 & 52.84 \\
\hline Total US & 131 & 137 & 124 & 123 & 116 & 120 & 118 & 14.19 & 14.44 & 13.38 & 13.47 & 12.89 & 13.26 & 13.41 \\
\hline Total Ex-US & 792 & 812 & 803 & 790 & 784 & 785 & 762 & 85.81 & 85.56 & 86.62 & 86.53 & 87.11 & 86.74 & 86.59 \\
\hline Total Global & 923 & 949 & 927 & 913 & 900 & 905 & 880 & 100 & 100 & 100 & 100 & 100 & 100 & 100 \\
\hline
\end{tabular}

Data Source: We are indebted to Dr. Andreas Schick and Qiyu Liu at the US Food and Drug Administration for making this data available to us in Excel files. 
Table 2- Number and Share of FDA FDF Facility Sites by Global Region, Annually, 2013-2019

\begin{tabular}{|c|c|c|c|c|c|c|c|c|c|c|c|c|c|c|}
\hline \multirow[b]{2}{*}{ Global Regions } & \multicolumn{7}{|c|}{ Number of FDF Facilities by Global Regions } & \multicolumn{7}{|c|}{ Share of FDF Facilities by Global Regions } \\
\hline & 2013 & 2014 & 2015 & 2016 & 2017 & 2018 & 2019 & 2013 & 2014 & 2015 & 2016 & 2017 & 2018 & 2019 \\
\hline \multicolumn{15}{|l|}{ Americas } \\
\hline USA & 288 & 283 & 285 & 278 & 288 & 305 & 288 & 42.73 & 40.84 & 40.03 & 39.6 & 40.51 & 41.44 & 39.94 \\
\hline CAN & 34 & 30 & 30 & 31 & 30 & 30 & 23 & 5.04 & 4.33 & 4.21 & 4.42 & 4.22 & 4.08 & 3.19 \\
\hline MEX & 4 & 3 & 3 & 4 & 4 & 4 & 3 & 0.59 & 0.43 & 0.42 & 0.57 & 0.56 & 0.54 & 0.42 \\
\hline ARG & 3 & 3 & 3 & 3 & 3 & 3 & 2 & 0.45 & 0.43 & 0.42 & 0.43 & 0.42 & 0.41 & 0.28 \\
\hline Other & 4 & 4 & 4 & 3 & 2 & 2 & 2 & 0.59 & 0.58 & 0.56 & 0.43 & 0.28 & 0.27 & 0.28 \\
\hline Sub-total & 333 & 323 & 325 & 319 & 327 & 344 & 318 & 49.41 & 46.61 & 45.65 & 45.44 & 45.99 & 46.74 & 44.11 \\
\hline \multicolumn{15}{|l|}{ Europe } \\
\hline FRA & 9 & 12 & 12 & 15 & 12 & 11 & 12 & 1.34 & 1.73 & 1.69 & 2.14 & 1.69 & 1.49 & 1.66 \\
\hline GER & 25 & 28 & 31 & 29 & 28 & 23 & 23 & 3.71 & 4.04 & 4.35 & 4.13 & 3.94 & 3.13 & 3.19 \\
\hline ITA & 22 & 24 & 22 & 21 & 22 & 22 & 22 & 3.26 & 3.46 & 3.09 & 2.99 & 3.09 & 2.99 & 3.05 \\
\hline GBR & 8 & 10 & 6 & 8 & 7 & 7 & 5 & 1.19 & 1.44 & 0.84 & 1.14 & 0.98 & 0.95 & 0.69 \\
\hline $\mathrm{IRL}$ & 6 & 5 & 7 & 5 & 4 & 4 & 5 & 0.89 & 0.72 & 0.98 & 0.71 & 0.56 & 0.54 & 0.69 \\
\hline Rest - Eastern & 19 & 21 & 21 & 19 & 16 & 17 & 18 & 2.82 & 3.03 & 2.95 & 2.71 & 2.25 & 2.31 & 2.5 \\
\hline Rest - Western & 40 & 42 & 45 & 45 & 49 & 50 & 51 & 5.93 & 6.06 & 6.32 & 6.41 & 6.89 & 6.79 & 7.07 \\
\hline Sub-total & 129 & 142 & 144 & 142 & 138 & 134 & 136 & 19.14 & 20.49 & 20.22 & 20.23 & 19.41 & 18.21 & 18.86 \\
\hline \multicolumn{15}{|l|}{ Asia Rest - World } \\
\hline IND & 136 & 141 & 153 & 149 & 156 & 160 & 163 & 20.18 & 20.35 & 21.49 & 21.23 & 21.94 & 21.74 & 22.61 \\
\hline $\mathrm{CHN}$ & 36 & 43 & 43 & 51 & 51 & 54 & 59 & 5.34 & 6.2 & 6.04 & 7.26 & 7.17 & 7.34 & 8.18 \\
\hline ISR & 7 & 6 & 7 & 7 & 7 & 7 & 7 & 1.04 & 0.87 & 0.98 & 1 & 0.98 & 0.95 & 0.97 \\
\hline TWN & 11 & 14 & 15 & 14 & 15 & 18 & 18 & 1.63 & 2.02 & 2.11 & 1.99 & 2.11 & 2.45 & 2.5 \\
\hline Rest - World & 22 & 24 & 25 & 20 & 17 & 19 & 20 & 3.26 & 3.46 & 3.51 & 2.85 & 2.39 & 2.58 & 2.77 \\
\hline Sub-total & 212 & 228 & 243 & 241 & 246 & 258 & 267 & 31.45 & 32.9 & 34.13 & 34.33 & 34.6 & 35.05 & 37.03 \\
\hline Total US & 288 & 283 & 285 & 278 & 288 & 305 & 288 & 42.73 & 40.84 & 40.03 & 39.6 & 40.51 & 41.44 & 39.94 \\
\hline Total Ex-US & 386 & 410 & 427 & 424 & 423 & 431 & 433 & 57.27 & 59.16 & 59.97 & 60.4 & 59.49 & 58.56 & 60.06 \\
\hline Total Global & 674 & 693 & 712 & 702 & 711 & 736 & 721 & 100 & 100 & 100 & 100 & 100 & 100 & 100 \\
\hline
\end{tabular}

Data Source: We are indebted to Dr. Andreas Schick and Qiyu Liu at the US Food and Drug Administration for making this data available to us in Excel files. 
Table 3 - Number and Share of FDA API Facility Sites by US FDA Region Annually, 2013-2019

\begin{tabular}{|c|c|c|c|c|c|c|c|c|c|c|c|c|c|c|}
\hline \multirow{2}{*}{ FDA Regions } & \multicolumn{7}{|c|}{ Number of API Facilities by Domestic Region } & \multicolumn{7}{|c|}{ Share of API Facilities by Domestic Region } \\
\hline & 2013 & 2014 & 2015 & 2016 & 2017 & 2018 & 2019 & 2013 & 2014 & 2015 & 2016 & 2017 & 2018 & 2019 \\
\hline \multicolumn{15}{|l|}{ Southeast } \\
\hline ATL & 15 & 17 & 15 & 14 & 15 & 15 & 14 & 11.45 & 12.41 & 12.1 & 11.38 & 12.93 & 12.5 & 11.86 \\
\hline FLA & 0 & 0 & 0 & 1 & 1 & 1 & 1 & 0 & 0 & 0 & 0.81 & 0.86 & 0.83 & 0.85 \\
\hline NOL & 9 & 10 & 9 & 8 & 8 & 7 & 5 & 6.87 & 7.3 & 7.26 & 6.5 & 6.9 & 5.83 & 4.24 \\
\hline SJN & 6 & 5 & 5 & 4 & 2 & 3 & 1 & 4.58 & 3.65 & 4.03 & 3.25 & 1.72 & 2.5 & 0.85 \\
\hline Sub-total & 30 & 32 & 29 & 27 & 26 & 26 & 21 & 22.9 & 23.36 & 23.39 & 21.94 & 22.41 & 21.66 & 17.8 \\
\hline \multicolumn{15}{|l|}{ Other East } \\
\hline BLT & 2 & 2 & 2 & 1 & 1 & 1 & 1 & 1.53 & 1.46 & 1.61 & 0.81 & 0.86 & 0.83 & 0.85 \\
\hline NWE & 6 & 6 & 4 & 4 & 4 & 4 & 4 & 4.58 & 4.38 & 3.23 & 3.25 & 3.45 & 3.33 & 3.39 \\
\hline NWJ & 11 & 14 & 15 & 13 & 12 & 12 & 12 & 8.4 & 10.22 & 12.1 & 10.57 & 10.34 & 10 & 10.17 \\
\hline NYK & 5 & 6 & 5 & 5 & 5 & 7 & 8 & 3.82 & 4.38 & 4.03 & 4.07 & 4.31 & 5.83 & 6.78 \\
\hline $\mathrm{PHI}$ & 10 & 12 & 12 & 10 & 11 & 11 & 13 & 7.63 & 8.76 & 9.68 & 8.13 & 9.48 & 9.17 & 11.02 \\
\hline Sub-total & 34 & 40 & 38 & 33 & 33 & 35 & 38 & 25.96 & 29.2 & 30.65 & 26.83 & 28.44 & 29.16 & 32.21 \\
\hline \multicolumn{15}{|l|}{ Central } \\
\hline $\mathrm{CHI}$ & 10 & 13 & 10 & 11 & 11 & 11 & 10 & 7.63 & 9.49 & 8.06 & 8.94 & 9.48 & 9.17 & 8.47 \\
\hline CIN & 10 & 10 & 10 & 9 & 8 & 10 & 10 & 7.63 & 7.3 & 8.06 & 7.32 & 6.9 & 8.33 & 8.47 \\
\hline DAL & 7 & 6 & 5 & 5 & 4 & 4 & 3 & 5.34 & 4.38 & 4.03 & 4.07 & 3.45 & 3.33 & 2.54 \\
\hline DET & 9 & 6 & 5 & 6 & 5 & 5 & 6 & 6.87 & 4.38 & 4.03 & 4.88 & 4.31 & 4.17 & 5.08 \\
\hline KAN & 13 & 11 & 10 & 11 & 11 & 12 & 12 & 9.92 & 8.03 & 8.06 & 8.94 & 9.48 & 10 & 10.17 \\
\hline MIN & 8 & 7 & 6 & 6 & 6 & 6 & 6 & 6.11 & 5.11 & 4.84 & 4.88 & 5.17 & 5 & 5.08 \\
\hline Sub-total & 57 & 53 & 46 & 48 & 45 & 48 & 47 & 43.5 & 38.69 & 37.08 & 39.03 & 38.79 & 40 & 39.81 \\
\hline \multicolumn{15}{|l|}{ West } \\
\hline DEN & 4 & 4 & 4 & 6 & 5 & 4 & 4 & 3.05 & 2.92 & 3.23 & 4.88 & 4.31 & 3.33 & 3.39 \\
\hline LOS & 6 & 7 & 7 & 8 & 7 & 7 & 8 & 4.58 & 5.11 & 5.65 & 6.5 & 6.03 & 5.83 & 6.78 \\
\hline SAN & 0 & 0 & 0 & 0 & 0 & 0 & 0 & 0 & 0 & 0 & 0 & 0 & 0 & 0 \\
\hline SEA & 0 & 1 & 0 & 1 & 0 & 0 & 0 & 0 & 0.73 & 0 & 0.81 & 0 & 0 & 0 \\
\hline Sub-total & 10 & 12 & 11 & 15 & 12 & 11 & 12 & 7.63 & 8.76 & 8.88 & 12.19 & 10.34 & 9.16 & 10.17 \\
\hline Total Domestic & 131 & 137 & 124 & 123 & 116 & 120 & 118 & 100 & 100 & 100 & 100 & 100 & 100 & 100 \\
\hline Domestic Mean Per Region & 6.89 & 7.21 & 6.53 & 6.47 & 6.11 & 6.32 & 6.21 & 5.26 & 5.26 & 5.26 & 5.26 & 5.26 & 5.26 & 5.26 \\
\hline
\end{tabular}

Data Source: We are indebted to Dr. Andreas Schick and Qiyu Liu at the US Food and Drug Administration for making this data available to us in Excel files.

Notes: The states/districts/territories in each FDA region are as follows: ATL (Georgia, North Carolina, South Carolina); BLT (Maryland, District of Columbia); CHI (Illinois); CIN (Kentucky, Ohio); DAL (Arkansas, Oklahoma, Texas); DEN (Colorado, New Mexico, Utah, Wyoming); DET (Indiana, Michigan); FLA (Florida); KAN (lowa, Kansas, Missouri, Nebraska); LOS (Arizona, Southern California); MIN (Minnesota, North Dakota, South Dakota, Wisconsin); NWE (Connecticut, Maine,

Massachusetts, New Hampshire, Rhode Island, Vermont); NWJ (New Jersey); NOL (Alabama, Louisiana, Mississippi, Tennessee); NYK (New York); PHI (Delaware, Pennsylvania); SAN (Northern California, Hawaii, Nevada); SJN (Puerto Rico, US Virgin Islands); SEA (Alaska, Idaho, Montana, Oregon, Washington). Data Source: The list of states covered by each of the 19 FDA US regions is taken from https://www.fda.gov/about-fda/contact-ora/ora-district-directors. 
Table 4 - Number and Share of FDF Facility Sites by US FDA Region Annually, 2013-2019

\begin{tabular}{|c|c|c|c|c|c|c|c|c|c|c|c|c|c|c|}
\hline \multirow[b]{2}{*}{ FDA Regions } & \multicolumn{7}{|c|}{ Number Of FDF Facilities by Domestic Region } & \multicolumn{7}{|c|}{ Share of FDF Facilities by Domestic Region } \\
\hline & 2013 & 2014 & 2015 & 2016 & 2017 & 2018 & 2019 & 2013 & 2014 & 2015 & 2016 & 2017 & 2018 & 2019 \\
\hline \multicolumn{15}{|l|}{ Southeast } \\
\hline ATL & 29 & 29 & 30 & 31 & 27 & 35 & 31 & 10.07 & 10.25 & 10.53 & 11.15 & 9.38 & 11.48 & 10.76 \\
\hline FLA & 19 & 17 & 18 & 17 & 17 & 17 & 10 & 6.6 & 6.01 & 6.32 & 6.12 & 5.9 & 5.57 & 3.47 \\
\hline NOL & 9 & 9 & 6 & 8 & 7 & 7 & 6 & 3.13 & 3.18 & 2.11 & 2.88 & 2.43 & 2.3 & 2.08 \\
\hline SJN & 9 & 9 & 10 & 15 & 11 & 10 & 11 & 3.13 & 3.18 & 3.51 & 5.4 & 3.82 & 3.28 & 3.82 \\
\hline Sub-total & 66 & 64 & 64 & 71 & 62 & 69 & 58 & 22.93 & 22.62 & 22.47 & 25.55 & 21.53 & 22.63 & 20.13 \\
\hline \multicolumn{15}{|l|}{ Other East } \\
\hline BLT & 8 & 9 & 10 & 9 & 9 & 9 & 9 & 2.78 & 3.18 & 3.51 & 3.24 & 3.13 & 2.95 & 3.13 \\
\hline NWE & 12 & 10 & 10 & 10 & 11 & 12 & 9 & 4.17 & 3.53 & 3.51 & 3.6 & 3.82 & 3.93 & 3.13 \\
\hline NWJ & 42 & 42 & 42 & 42 & 47 & 46 & 44 & 14.58 & 14.84 & 14.74 & 15.11 & 16.32 & 15.08 & 15.28 \\
\hline NYK & 36 & 35 & 33 & 30 & 32 & 37 & 38 & 12.5 & 12.37 & 11.58 & 10.79 & 11.11 & 12.13 & 13.19 \\
\hline PHI & 18 & 18 & 18 & 14 & 20 & 20 & 17 & 6.25 & 6.36 & 6.32 & 5.04 & 6.94 & 6.56 & 5.9 \\
\hline Sub-total & 116 & 114 & 113 & 105 & 119 & 124 & 117 & 40.28 & 40.28 & 39.66 & 37.78 & 41.32 & 40.65 & 40.63 \\
\hline \multicolumn{15}{|l|}{ Central } \\
\hline $\mathrm{CHI}$ & 15 & 13 & 13 & 11 & 11 & 12 & 14 & 5.21 & 4.59 & 4.56 & 3.96 & 3.82 & 3.93 & 4.86 \\
\hline CIN & 14 & 14 & 14 & 13 & 13 & 13 & 15 & 4.86 & 4.95 & 4.91 & 4.68 & 4.51 & 4.26 & 5.21 \\
\hline DAL & 12 & 12 & 12 & 11 & 12 & 13 & 10 & 4.17 & 4.24 & 4.21 & 3.96 & 4.17 & 4.26 & 3.47 \\
\hline DET & 15 & 17 & 16 & 16 & 15 & 15 & 15 & 5.21 & 6.01 & 5.61 & 5.76 & 5.21 & 4.92 & 5.21 \\
\hline KAN & 9 & 8 & 9 & 9 & 9 & 11 & 12 & 3.13 & 2.83 & 3.16 & 3.24 & 3.13 & 3.61 & 4.17 \\
\hline MIN & 5 & 6 & 7 & 7 & 7 & 8 & 8 & 1.74 & 2.12 & 2.46 & 2.52 & 2.43 & 2.62 & 2.78 \\
\hline Sub-total & 70 & 70 & 71 & 67 & 67 & 72 & 74 & 24.32 & 24.74 & 24.91 & 24.12 & 23.27 & 23.6 & 25.7 \\
\hline \multicolumn{15}{|l|}{ West } \\
\hline DEN & 11 & 12 & 13 & 14 & 14 & 13 & 14 & 3.82 & 4.24 & 4.56 & 5.04 & 4.86 & 4.26 & 4.86 \\
\hline LOS & 24 & 22 & 22 & 20 & 24 & 25 & 23 & 8.33 & 7.77 & 7.72 & 7.19 & 8.33 & 8.2 & 7.99 \\
\hline SAN & 0 & 0 & 0 & 0 & 0 & 0 & 0 & 0 & 0 & 0 & 0 & 0 & 0 & 0 \\
\hline SEA & 1 & 1 & 2 & 1 & 2 & 2 & 2 & 0.35 & 0.35 & 0.7 & 0.36 & 0.69 & 0.66 & 0.69 \\
\hline Sub-total & 36 & 35 & 37 & 35 & 40 & 40 & 39 & 12.5 & 12.36 & 12.98 & 12.59 & 13.88 & 13.12 & 13.54 \\
\hline Total Domestic & 288 & 283 & 285 & 278 & 288 & 305 & 288 & 100 & 100 & 100 & 100 & 100 & 100 & 100 \\
\hline Domestic Mean Per Region & 15.16 & 14.89 & 15 & 14.63 & 15.16 & 16.05 & 15.16 & 5.26 & 5.26 & 5.26 & 5.26 & 5.26 & 5.26 & 5.26 \\
\hline
\end{tabular}

Data Source: We are indebted to Dr. Andreas Schick and Qiyu Liu at the US Food and Drug Administration for making this data available to us in Excel files.

Notes: The states/districts/territories in each FDA region are as follows: ATL (Georgia, North Carolina, South Carolina); BLT (Maryland, District of Columbia); CHI (Illinois); CIN (Kentucky, Ohio); DAL (Arkansas, Oklahoma, Texas); DEN (Colorado, New Mexico, Utah, Wyoming); DET (Indiana, Michigan); FLA (Florida); KAN (lowa, Kansas, Missouri, Nebraska); LOS (Arizona, Southern California); MIN (Minnesota, North Dakota, South Dakota, Wisconsin); NWE (Connecticut, Maine, Massachusetts, New Hampshire, Rhode Island, Vermont); NWJ (New Jersey); NOL (Alabama, Louisiana, Mississippi, Tennessee); NYK (New York); PHI (Delaware, Pennsylvania); SAN (Northern California, Hawaii, Nevada); SJN (Puerto Rico, US Virgin Islands); SEA (Alaska, Idaho, Montana, Oregon, Washington). Data Source: The list of states covered by each of the 19 FDA US regions is taken from https://www.fda.gov/about-fda/contact-ora/ora-district-directors. 
Appendix: $\quad$ Industry Strategy and Public Policy in Four Prominent Pharmaceutical Manufacturing Geographies

\section{A. Puerto Rico}

The U.S. acquired Puerto Rico from Spain in 1898 in the aftermath of the SpanishAmerican War. Even after the 1952 federal ratification of the Puerto Rican constitution giving the island a "Commonwealth" label and allowing it limited autonomy to deal with local affairs, the island was still legally considered a territory and therefore under the ultimate control of the U.S. Congress. ${ }^{59}$

Unlike the evolution of the pharmaceutical industry as a conscious targeted national policy tool to substitute away from costly imported drugs and to provide low-cost drugs to its very large populations, as was the case in India and China, in the case of Puerto Rico the U.S. Congress passed legislation incentivizing manufacturing employment in its Puerto Rico territory. Special tax breaks for the island began in its earliest days as a way to subsidize the sugar industry, and then in the mid- $20^{\text {th }}$ century as a way to bring low-wage manufacturing to Puerto Rico, often at the expense of local business and the Puerto Rican consumer. A 1901 U.S. Supreme Court ruling allowed for implementation of non-uniform tax laws in territories like Puerto Rico, enabling Congress to treat the island as a foreign entity for purposes of taxation. ${ }^{60}$

One particular tax provision, called Section 936, incentivized the location of pharmaceutical manufacturing in Puerto Rico by granting U.S.-based corporations a tax exemption on income earned in Puerto Rico. Subsidiaries of branded and generic companies would develop a drug in their U.S. R\&D facilities, transfer the patent or proprietary technical

\footnotetext{
${ }^{59}$ Manuel Madrid, “How the Tax Cut Sacks Puerto Rico”, American Prospect, June 28, 2018, p. 2 of 9. Available online at https://prospect.org/article/how-tax-cut-sacks-puerto-rico.

${ }^{60}$ Ibid., p. 3 of 9.
} 
knowledge to their wholly owned subsidiaries operating in Puerto Rico, and claim the income from the drug sales as tax-free income. ${ }^{61}$ Many branded pharmaceutical, biotechnology, and medical device companies opened manufacturing plants in Puerto Rico. Generic pharmaceutical companies such as Teva, Ivax and Watson also located manufacturing plants in Puerto Rico following passage of the Section 936 legislation. ${ }^{62}$

President Clinton signed a repeal of the Section 936 provisions in 1996, and over the next ten years it was gradually phased out, eliminated entirely at the end of 2005, resulting in plant closures and declining employment, ${ }^{63}$ and imposing an allegedly disproportionate tax burden on domestic Puerto Rican companies. ${ }^{64}$

The U.S. Tax Cuts and Job Act of 2017 targeted placing a tax on foreign firms owned by U.S. investors. Its implementation penalized tax "inversions", and is alleged to have had a disproportionate negative impact on Puerto Rico, since it targeted income from "intangible" assets such as pharmaceuticals and medical devices, on which Puerto Rico has been heavily reliant. ${ }^{65}$ The Puerto Rican economy was then dealt a further blow in 2017 when hit by the devastating Hurricane Maria. ${ }^{66}$

\footnotetext{
61 “The End of Section 936”, Puerto Rico Report, posted August 29, 2016. Available online at https://www.puertoricoreport.com. f

62 “Puerto Rico’s Pharmaceutical Industry ‘Terminally Ill', November 19, 2007, pp. 2 and 3 o 4. Available online at https://www.manufacturing.net/news//2007/11/puerto-ricos-pharmaceutical-industry-terminally...

63 “The End of Section 936” [2016], op. cit., p. 2.

64 "Puerto Rico's Pharmaceutical Industry “Terminally Ill’”,[2007] op. cit., pp.1,4 of 8. Also see Scott Greenberg and Gavin Ekins, “Tax Policy Helped Create Puerto Rico’s Fiscal Crisis”, The Tax Foundation, June 30, 2015, pp. 1-4 of 5. Available online at https://taxfoundation.org/tax-policy-helped-create-puerto-rico-s-fiscal-crisis/.

${ }^{65}$ Manuel Madrid [2018], op. cit., p. 4 of 9.

${ }^{66}$ For a description of the effects of the September 2017 Hurricane Maria on pharmaceutical operations in Puerto Rico, see Department of Homeland Security, Threats to Pharmaceutical Supply Chains: The Public-Private Analytic Exchange Program, Research Findings, July 2018. Available online at https://www.dhs.gov/sites/default/files/publications/2018 AEP Threats to Pharmaceutical Supply Chains.pdf.
} 
Until the phase-out of Section 936 in 2005, Puerto Rican API and FDF manufacturing sites were a major supplier to the mainland U.S. pharmaceutical market, but since then Puerto Rico's role as an API and FDF supplier to the U.S. mainland has gradually declined. ${ }^{67}$

\section{B. INDIA}

At the time it gained Independence in 1947, India recognized product patents. Its pharmaceutical market was dominated by multinational firms controlling between 80 and 90 percent of the market, primarily by importing bulk drugs from abroad and having their Indian subsidiaries manufacture and sell the formulations. ${ }^{68}$ Pharmaceutical prices were high, and much of India's large population lacked access to low-priced medicines. ${ }^{69}$

In the decades that followed, India embarked on a policy of incentivizing domestic production of low-price pharmaceuticals to substitute against costly imports. Manufacturing competence gradually emerged as a comparative advantage, facilitated in part by the Patent Act of 1970 that replaced product with process patents, enabling the country to develop a skilled labor force experienced in reverse engineering. As long as the manufacturing process of a drug differed from that of the patented product, India patent law and regulatory policies allowed Indian manufacturers to sell pharmaceuticals domestically at a fraction of their cost in the West. Gradually by the 1980s India became self-sufficient in pharmaceutical manufacturing, exploiting its comparative advantage built largely on learning how to reverse engineer drugs.

\footnotetext{
67 “Puerto Rico’s Pharmaceutical Industry 'Terminally Ill’,’[2007], op. cit.. Nonetheless, citing a November 6, 2017 US Food and Drug Administration press release, a 2018 Department of Homeland Security study claimed "According to the FDA, Puerto Rico produces 40 billion dollars-worth of pharmaceutical products yearly, more than any other US state or foreign country, by value”. See Department of Homeland Security [2018], op. cit., p. 4 of 18. ${ }^{68}$ William Greene, “The Emergence of India’s Pharmaceutical Industry and Implications for the U.S. Generic Drug Market”, Washington DC: U.S. International Trade Commission, Office of Economics Working Paper No. 2007-05A, May 2007, p. 2 of 36.

${ }^{69}$ Chiranjib Neogi, Atsuko Kamiike, Takahiro Sato, "Identification of Factors Behind Performance of Pharmaceutical Industries in India”, Kobe, Japan: Kobe University, Research Institute for Economics and Business Administration, Discussion Paper DP2012-23, September 28, 2012.
} 
However, the lack of intellectual property protection for product patents limited India's ability to expand globally and to achieve external and internal economies of scale. So in 1995 India sought to become a member country of the World Trade Organization ("WTO”). To do so, it had to agree to comply with the Agreement on Trade-Related Aspects of Intellectual Property Rights (“TRIPS"), which in turn required India to amend its Patent Act of 1970. The Patent Act amendments took effect in 2005, forcing India to reintroduce pharmaceutical product patents, and also to assure intellectual property protection for both product and process patents for 20 years from date of issue, with some qualifications. ${ }^{70}$

In the years that followed, India nurtured and exploited further its comparative advantages - its lower production and research costs, its large pool of low cost technical and scientifically trained personnel (including those experienced in reverse engineering), and the large number of FDA-certified manufacturing plants located in India. Tax policies fostered the growth of geographic manufacturing clusters through Special Enterprise Zone provisions, thereby achieving external scale economies. ${ }^{71}$ Price controls were introduced, and fierce competition between thousands of small and medium-size firms resulted in a decline in the number of small, inefficient firms that either exited the market or were acquired by larger Indian or foreign firms seeking to take advantage of internal scale economies, thereby becoming competitive with large multinational companies. Many Indian companies repurposed themselves as contract manufacturers, producing bulk and intermediate products, APIs for new chemical entities, or APIs or FDFs for generic drugs in cooperation with foreign multinational companies. In 2016, about 35\% of the APIs manufactured in India were exported to the US, UK or Japan. In

\footnotetext{
${ }^{70}$ Neogi, Kamiike, and Sato [2012], op. cit., pp. 4-5 of 35.

${ }^{71}$ Gulshan Akhtar, "Indian Pharmaceutical Industry: An Overview”, IOSR Journal of Humanities and Social Science, July-August 2013, 13(3):55,63.
} 
turn, approximately $32 \%$ of domestic consumption of APIs were imported, with China alone accounting for $57-60 \%$ of the APIs by rupees imported by India. ${ }^{72}$

The global role of Indian generic drug companies in the U.S. market has changed dramatically in the last few years. One observer has described the changing industry environment as follows:

"Starting from around late 2018 to early 2019, traditional generics bigwigs Teva, Mylan, Novartis' Sandoz, Amneal and Endo have lost out to a group of six competitors that include Indian drugmakers Aurobindo Pharma, Lupin, Dr. Reddy’s, Sun Pharma, Cipla and Canada's Apotex in terms of weekly total prescriptions... ....Amid increased pricing pressure and competition in the generic arena, higher-margin complex generics and biosimilars have lately been put at the top of the growth agenda at Teva, Mylan and Sandoz, the top 3 U.S. generics players by total prescriptions in 2017. The old idea of 'first in, last out' or just waiting out lower-priced competitors until they give up and exit has died...Companies are no longer trying to drive as much volume as possible, but rather are focused on the margin of those sales...'Old guard' firms are filing as many U.S. generic applications as before, but they're being more careful about which ones they launch....Companies these days don't always choose to launch generics even though they are receiving approvals at a similar or greater pace."73

\section{CHINA}

As with India, the current state of the Chinese pharmaceutical industry reflects in large part the impacts of its history as a command rather than market-driven economy. State-owned Chinese companies produced tablet dosage forms and distributed them to hospitals, the primary consumer of pharmaceuticals. Governments or rural collective economic organizations took control of all funds earned by hospitals and clinics, and spent them. Because they had no

\footnotetext{
${ }^{72}$ Associated Chambers of Commerce and Industry of India (ASSOCHAM India) and RNCOS Business Consulting Services, Indian API Market Outlook 2022, 2017, Figures 1-1 and 1-2, pages 1 and 2. In volume terms, of its imported API in 2018, India imported 80\% from China. Deepak Patel, "Pharma Sector: 80 percent APIs via Chinese imports despite similar making costs”, Indian Express, June 19, 2018. Available online at https://indianexpress.com/article/business/business-others/pharma-sector-80-per-cent-apis-via-chinese-importsdespite-similar-making-costs-5222951/.

73 Angus Liu, “"”'Old guard' generics players yield U.S. lead to Indian up-and-comers: analyst”, Fierce Pharma, April 18, 2019. Available online at https://www.fiercepharma.com/pharma/generics-old-guard-pack-y ields-u-sscripts-lead-to-..., pp. 2, 3, and 5 of 5.
} 
motivation to pursue profits, these institutions simply followed the orders of the government without pursuing strong independent interests. The need to exert tight control over the quality and safety of medicines in hospitals and clinics was not urgent. Counterfeiting was not a problem, because the state enterprises had no incentive to produce them. With no counterfeit drugs, there was little if any motivation to monitor the safety and quality of drugs. ${ }^{74}$

Thus, when China entered the post-reform era in the 1970s and 1980s, the highly fragmented Chinese pharmaceutical industry faced many new challenges. Potential external and internal scale economies had not been exploited. Domestic companies had largely been government owned, and fraught with overproduction and losses. Even today, most Chinese companies - even joint ventures - compete with each other for the same generics. As of 2011, more than $80 \%$ of the manufacturers in China were either not capable of supplying to Western regulated pharmaceutical markets or had chosen instead to focus on the local patient population. ${ }^{75}$ As a result, currently most manufacturers rely on the repetitive production of low value-added bulk pharmaceuticals and imitation drugs. Many are struggling for survival; more than 32\% recorded losses in 1999, according to the Pharmaceutical Department of National Development and Reform Commission. ${ }^{76}$ Moreover, since 2004 the State Food and Drug Administration ("SFDA") has been closing down manufacturers that do not meet China's increasingly stringent Good Manufacturing Practices standards for products intended for domestic consumption, resulting in slowdowns in domestic production of API, but possibly

\footnotetext{
${ }^{74}$ Haona Li, He Sun, and Frances J. Richmond, “The Historical Evolution of China’s Drug Regulatory System”, Discussion Paper, University of Southern California, International Center for Regulatory Science, August 2014. Available online at https://regulatory.usc.edu/files/2014/08/Evolution China Reg system 2014.pdf.

${ }^{75}$ Shannon Bennett, “China’s growing presence in the global supply chain”, Chemistry Today, January/February 2012, 30(1), p. 1 of 3.

${ }^{76}$ Wikipedia, "Pharmaceutical industry in China", last edited on 7 May 2019, pp. 1,3, 4, 6 of 22. Available online at https://en.wikipedia.org/w/index.php?title=Pharmaceutical industry-in-China\&old id=895942969.
} 
providing incentives for consolidation and achievement of scale and scope economies by domestic or foreign companies. ${ }^{77}$

These characteristics of the Chinese pharmaceutical market have led foreign investors in China to phase in their outsourcing efforts gradually. Attracted by China's comparative advantages in lower costs of manufacturing chemical and intermediate goods, lower investment costs, shorter lead times and access to the immense Asian talent pool, in the last decade foreign investors have initially limited outsourcing to old products and commodity APIs involving less sophisticated chemistry. ${ }^{78}$ The bulk drugs market has evolved rapidly over the years, and today it is large and diversified with about 7,000 API manufacturers. ${ }^{79}$ As of 2018, the Chinese API market is the second largest API market in the entire Pacific region, second only to Japan. ${ }^{80}$ But FDF products from China are still relatively rare in developed countries.

Moreover, China faces a major issue with intellectual property rights protection, which has resulted in a low level of market protection for domestic branded drugs, allowing established foreign generics and off-patent brands to dominate the domestic market. ${ }^{81}$ It is estimated that $80 \%$ of counterfeit products in China are consumed in rural areas, providing an opening for foreign pharmaceutical companies to develop the market in rural areas. ${ }^{82}$

\footnotetext{
77 Wikipedia [2019], op. cit., pp. 1 and 4 of 22.

${ }^{78}$ Kirsty Barnes, “China to play starring role in AstraZeneca API outsourcing”, InPharmaTechnologist, August 5, 2007, pp. 1-2. Available online at https://www.in-pharmatechnologist.com /Article/2007/07/05/China-to-playstarring-role-i...

79 Deepak Patel, “Pharma Sector: 80 percent APIs via Chinese imports despite similar making costs”, Indian Express, June 19, 2018. Available online at https://indianexpress.com/article/business/business-others/pharmasector-80-per-cent-apis-via-chinese-imports-despite-similar-making-costs-5222951/, p. 6 of 10.

${ }^{80}$ Business Wire, “2018 Market for Active Pharmaceutical Ingredients (APIs) in China”, Dublin, October 2, 2018. Available online at https://www.businesswire.com/.../2018-Market-Active-Pharmaceutical-Ingredients-API... ${ }^{81}$ Ibid.

${ }^{82}$ Wikipedia [2019], op. cit., pp. 1 and 4 of 22.
} 
Although China seeks to move up the value chain from manufacturing bulk, intermediate and APIs to producing and exporting FDFs, the facility and application fees associated with the 2013 implementation of the US' Generic Drug User Fee act may be sufficiently prohibitive to limit the number of Chinese companies focusing on pursuing the US' FDF market, instead preferring to invest in the rapidly growing Chinese FDF market. ${ }^{83}$

\section{IRELAND}

Unlike the import substitution public policies in India and China that sought directly to nurture a pharmaceutical manufacturing sector that could produce low-priced pharmaceuticals for their very large populations, and then have focused on exploiting potential internal and external scale and scope economies in developing a pharmaceutical export market, in Ireland tax policies have provided multinational companies incentives to locate their headquarters in Ireland, even if the companies' de facto operations are managed abroad. These tax policies are typically called tax inversions by tax authorities outside Ireland.

The ways by which Irish tax authorities define the base income and profits on which corporate taxes are assessed (called the base erosion and profit sharing - "BEPS" - tools), involve how depreciation on intangible assets such as intellectual property ("IP”) are taken into account, and likely affects incentives for foreign firms to locate their API and FDF manufacturing or other facilities in Ireland. Irish authorities levy tax assessments based on a worldwide income base, rather than a territorial one based on income earned on operations in Ireland. Hence, Ireland's public policies are less directly but nevertheless indirectly supportive of firms' locating their API and FDF manufacturing facilities in Ireland. However, beginning in 2017 and continuing thereafter, US and UK tax policy countermeasures to stem the flow of Irish

\footnotetext{
${ }^{83}$ Shannon Bennett [2012], op. cit., p. 1 of 3.
} 
corporate tax inversions may be mitigating these direct and indirect impacts on the location of API and FDF manufacturing facilities in Ireland. ${ }^{84}$

The taxing of foreign, particularly American, firms plays a disproportionate role in the Ireland economy. In 2016-2017, foreign firms paid 80\% of Irish corporate tax, employed 25\% of the Irish labor force (because of relatively high wages, they paid 50\% of the Irish salary tax), and created $57 \%$ of Irish non-farm value-added. U.S.-controlled firms represent almost all foreign firms in Ireland, in 2017 comprised 25 of the top Irish firms, and 70\% of the revenue of the top 50 Irish firms. By 2018, Ireland had received the most U.S. corporate tax inversions in history, with Apple accounting for one-fifth of Irish GDP. Academic research has ranked Ireland as the world's largest tax haven, even larger than the entire Caribbean tax haven system. ${ }^{85}$

Ireland's main BEPS tools use IP to effect the profit shift from higher-tax jurisdictions to Ireland via royalty payment schemes. To avoid paying Irish corporation tax on these shifted profits, the BEPS tools either transfer the profits to traditional tax havens having explicit 0\% corporate tax rates (with Ireland having bilateral tax treaties with more than 70 countries) via royalty payment schemes, or use intangible capital allowance schemes to write-off the profits against Irish tax. Ireland describes its IP-based BEPS tools as being part of the "knowledge economy"; however, U.S.-based tax academics describe Ireland's IP as "the leading taxavoidance vehicle in the world”. Not surprisingly, most U.S. multinationals in Ireland operate in the two largest Irish industries, namely, technology companies (including software) and life sciences. ${ }^{86}$

\footnotetext{
${ }^{84}$ Wikipedia, “Corporation tax in the Republic of Ireland”, last updated June 17, 2019, p. 12,13, and 25-29 of 55. Available online at https://en.wikipedia.org/w/index.php?title=Corporation tax in the Republic of Ireland 85 Wikipedia [2019], op. cit., p. 1 of 55.

${ }^{86}$ Ibid, pp. 1, 3, 12 of 55.hh
} 
Whereas Ireland's nominal "headline” corporate tax rate is $12.5 \%$, Ireland's BEPS tools reduce tax liabilities to an effective tax rate of $0 \%$ to $2.5 \%$, depending on which BEPS tool is used. ${ }^{87}$ By comparison, the average 2001-2006 effective corporate tax rate on pharmaceuticals in the US was estimated at $31.5 \%{ }^{88}$

The favorable tax regime in Ireland has created incentives for American companies with substantial IP assets to engage in corporate tax inversions - strategies in which a foreign multinational corporation acquires or merges with an Irish-based company, and then shifts its legal place of incorporation to Ireland to avail itself of Ireland's favorable corporate tax regime. Moreover, Ireland's corporate tax code has a holding company regime that enables the foreign multinational's new Irish-based legal headquarters to gain full Irish tax-relief on Irish withholding taxes and payment of dividends from Ireland. Not surprisingly, almost all tax inversions to Ireland have come from the U.S., and to a lesser extent, the UK. Pharmaceutical companies such as Actavis, Allergan, Endo, Pfizer, Mallinckrodt, Perrigo, Alkermes, Shire and Horizon either succeeded or at least attempted to engage in corporate tax inversions. ${ }^{89}$

Although the Irish tax provisions and implementation of BEPS tools have focused primarily on headquarter location issues, they have also impacted the location of API and FDF biopharmaceutical manufacturing activities. Indeed, Ireland's corporate BEPS tools emphasize job creation (either of Irish employees or of foreign employees to Ireland). ${ }^{90}$ To be eligible to utilize the Irish BEPS tools and their effective tax rates of $0 \%$ to $2.5 \%$, multinationals have been

\footnotetext{
${ }^{87}$ Ibid., p. 11 of 55.

${ }^{88}$ PricewaterhouseCoopers, Pharma 2020: Taxing times ahead. Which path will you take?, Pricewaterhouse Coopers, Pharmaceuticals and Life Sciences, not dated, Figure 4, p. 6. Available at www.pwc.com/phaarma2020. ${ }^{89}$ Wikipedia [2019], op. cit., pp. 21-25 of 55.

90 Notably, these incentives are augmented by an Irish immigration policy that admits foreign workers much more easily than currently does the US, and likely the UK if in fact the UK carries out its Brexit plans. For discussion, see Shawn Pogatchnik and Heather Long, "Despite Trump’s ire, Ireland expects to avoid any pain from U.S. tax overhaul”, Washington Post, December 13, 2017, p. 2 of 5. Available at www.washingtonpost.com/business/economy/trumps-tax-plan-see...
} 
required to meet conditions that document and prove a nexus between the IP and the BEPS tools they implement, such as carrying out a "relevant trade" on the IP in Ireland (e.g., manufacturing patented products), and documenting the level of Irish employment engaged in the "relevant activities" on the IP. ${ }^{91}$ According to one source, since 2008 the pharmaceutical industry has invested close to $€ 10$ billion in manufacturing and R\&D sites in Ireland. ${ }^{92}$

\footnotetext{
${ }^{91}$ Wikipedia [2019], op. cit., p. 8 of 55.

${ }^{92}$ Bernard Mallee, "Protecting Innovation in pharma is in Ireland's interests”. Irish Times, July 27, 2018, p. 1 of 2. Available online at https:/www.irishtimes.com/opinion/protecting-innovation-in-phaerma-is-in-Ireland-s-interests$\underline{1.3577483 .}$.
} 